\title{
Assessing feeder space access and commercial phytase production methods on performance of commercial broilers fed pelleted diets
}

\author{
Mark Edward Lemons
}

Follow this and additional works at: https://researchrepository.wvu.edu/etd

\footnotetext{
Recommended Citation

Lemons, Mark Edward, "Assessing feeder space access and commercial phytase production methods on performance of commercial broilers fed pelleted diets" (2015). Graduate Theses, Dissertations, and Problem Reports. 6059.

https://researchrepository.wvu.edu/etd/6059

This Thesis is protected by copyright and/or related rights. It has been brought to you by the The Research Repository @ WVU with permission from the rights-holder(s). You are free to use this Thesis in any way that is permitted by the copyright and related rights legislation that applies to your use. For other uses you must obtain permission from the rights-holder(s) directly, unless additional rights are indicated by a Creative Commons license in the record and/ or on the work itself. This Thesis has been accepted for inclusion in WVU Graduate Theses, Dissertations, and Problem Reports collection by an authorized administrator of The Research Repository @ WVU. For more information, please contact researchrepository@mail.wvu.edu.
} 
Assessing feeder space access and commercial phytase production methods on performance of commercial broilers fed pelleted diets

Mark Edward Lemons

Thesis submitted to the

Davis College of Agriculture, Natural Resources, and Design at

West Virginia University

In partial fulfillment of the requirements for the degree of

\author{
Master of Science \\ in \\ Nutritional and Food Science \\ Joseph S. Moritz, Ph.D., Chair \\ Janet C. Tou, Ph.D. \\ Eugene E. Felton, Ph.D.
}
Division of Animal and Nutritional Sciences
Morgantown, WV
2015

Keywords: phytase, feeder space access, feed composition, broiler performance, feed
manufacture

2015 Mark Edward Lemons 


\title{
ABSTRACT \\ Assessing feeder space access and commercial phytase production methods on performance of commercial broilers fed pelleted diets
}

\author{
Mark E. Lemons
}

Applied research conducted at universities is essential for further advancements in poultry science and ultimately the commercial poultry industry. One important area of applied nutrition research is examining production methods associated with the important feed additive/enzyme phytase. Exogenous phytase inclusion in poultry diets has consistently been associated with decreased diet cost, increased broiler performance, and reduction in negative environmental impact. However, thermal stability of commercial phytases are variable. Strategies for production of phytases that ultimately maintain activity after being subjected to the pelleting process is essential. Phytase manufacturers have modified production methods in an effort to maximize phytase thermal stability and efficiency. The first study (Chapter 2) describes two experiments that assessed the effects of particle size distribution and bulk density of the carbohydrate-lipid coating on phytase retention and broiler performance. This study demonstrated that phytase manufacturers should utilize large particle size and a low bulk density to maintain the greatest enzyme thermal stability. This study also demonstrated that phytase manufacturers should utilize a broad range particle size distribution with a low bulk density to create the most efficacious phytase in regards to phosphorus digestibility and broiler performance. These studies further demonstrated the importance of conducting a combination of in vivo and in vitro experiments to truly depict phytases efficacy. Another important area of research is assessing improvements in feed form on broiler performance. However, university research often utilizes small floor pens and feed pans that provide greater feeder space access than encountered in typical commercial production. Feeder space access may be an important variable that influences research results, especially coupled with differing compositions of feed that broilers receive in the feed pan. The second study (Chapter 3 ) describes a 2 × 2 factorial using the main effects: high or low feed composition $(70 \%$ vs $40 \%)$ and increased or industry feeder space access $(5.9 \mathrm{~cm} / \mathrm{bird}$ vs $1.2 \mathrm{~cm} / \mathrm{bird})$ to determine effects on broiler performance. This study showed that presenting a high feed composition resulted in improved broiler performance. Feeder space access also influenced broiler performance and interacted with the feed composition main effect. This suggests future research should consider feeder space access so that results are most relevant to the commercial broiler industry. 


\section{ACKNOWLEDGEMENTS}

I would first like to thank my advisor Dr. Joseph Moritz for his continued guidance and support throughout the past 4 years I've been in his research lab. To be a member of a renowned feed manufacture lab is extremely humbling and I am honored for the opportunity. The career development and networking opportunities he has presented me will ensure success in my future endeavors, and for that I am extremely grateful. Next, I would like to thank my committee members, Dr. Janet Tou and Dr. Eugene Felton for their continued support throughout my research. I would also like to thank all of the WVU staff and faculty for all the help they have provided me through the years. Feed manufacture research is extremely labor intensive; therefore I would like to extend sincere gratitude towards my fellow lab mates, both past and present, for all of their support and hard work throughout this journey: Kelley Wamsley, Ashley Evans, Kevin Shipe, Angela Lamp, John Boney, Grace McKenzie, Kolby Foltz, Brian Glover, Danielle Reese, and Brittany Diehl. Without all of their help, none of this would be possible. Lastly, I would like to thank my family: my parents Edward and Karen, my brother Matt, and my grandparents Calvin and Delphia. Without their continued support and constant motivation, I would have never completed this monumental task. 


\section{Table of Contents}

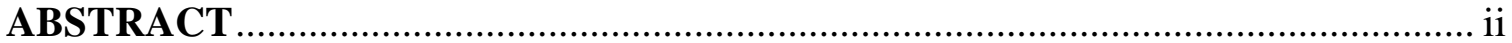

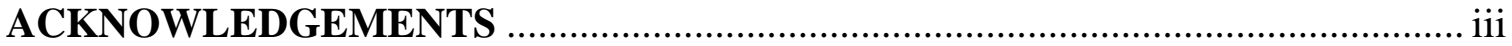

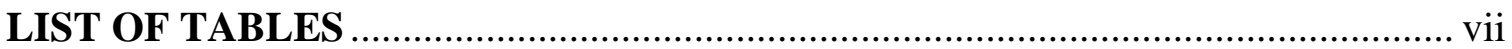

I. Poultry Production .....................................................................................

West Virginia Poultry Production ...........................................................................

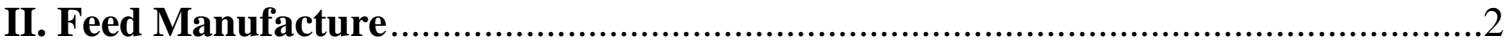

Diet Formulation/Pelleting Process ...........................................................................2

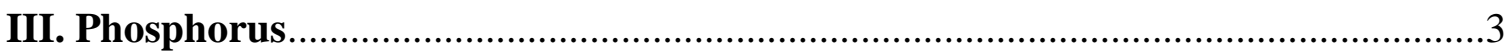

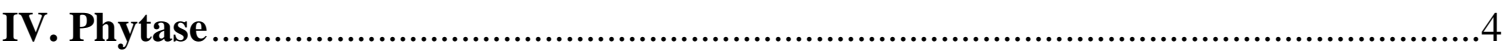

V. Feeder Space Access ..........................................................................................

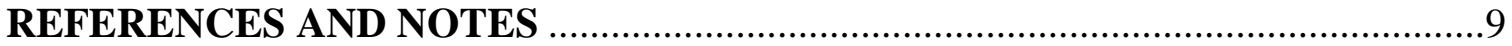

Chapter 2: Assessing particle size distribution and bulk density of an experimental phytase on phytase retention post-pelleting and 21 day broiler performance................................14

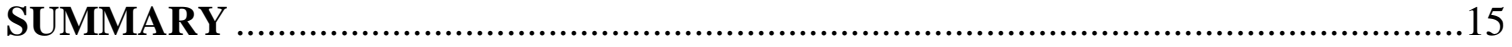

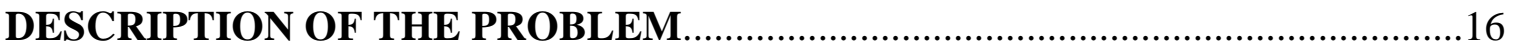

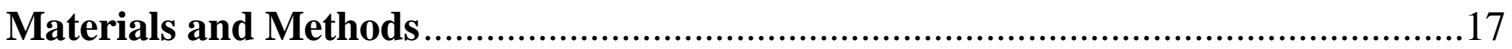

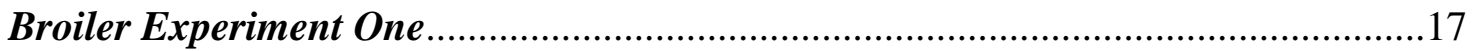

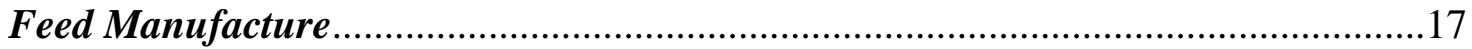

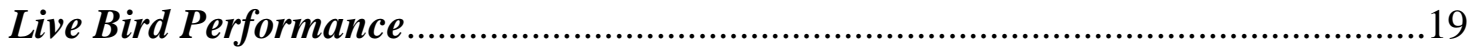


Broiler Experiment Two

Feed Manufacture.

Live Bird Performance.

.20

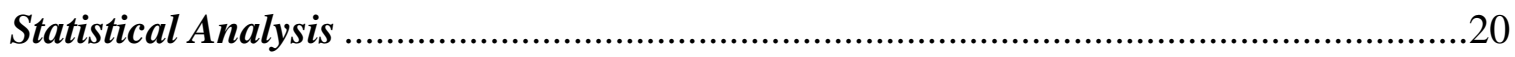

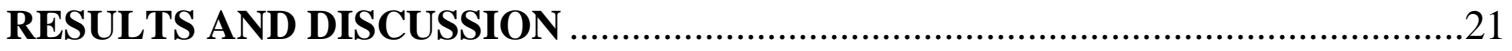

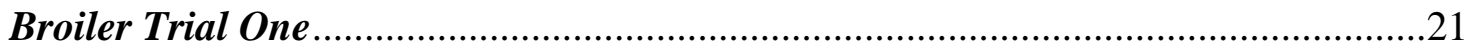

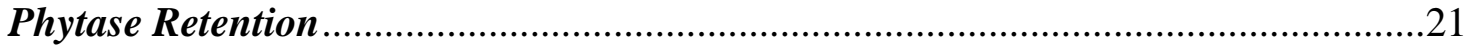

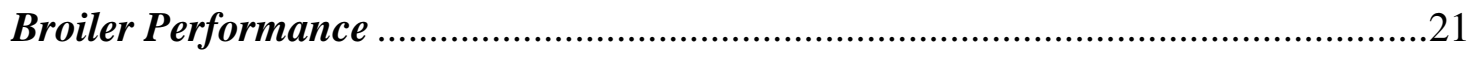

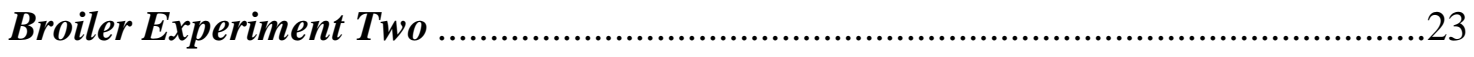

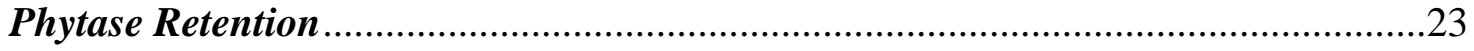

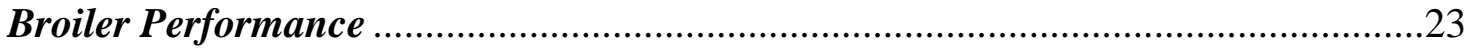

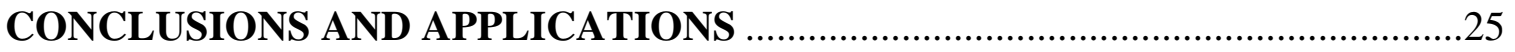

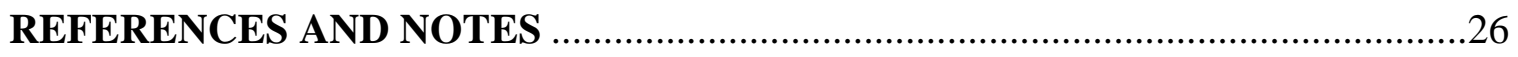

Table 1. Negative and Positive Control Diet Formulation for Broiler

Experiments One and Two

Table 2. Broiler Experiment One- Descriptive Feed Manufacture Data.............30

Table 3. Broiler Experiment Two- Descriptive Feed Manufacture Data ............31

Table 4. Analyzed Phytase Activity for Broiler Experiments One and Two.....32

Table 5. Broiler Experiment One - Performance Data (Hubbard x Cobb 500

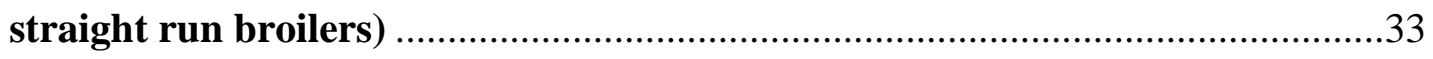


Table 6. Broiler Experiment Two- Performance Data (Hubbard x Cobb 500 straight run broilers)

Chapter 3: The effect of feeder space access and crumble/pellet composition on 38 day broiler performance .35

SUMMARY .36

DESCRIPTION OF THE PROBLEM .37

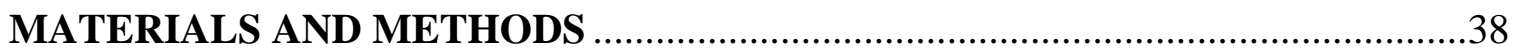

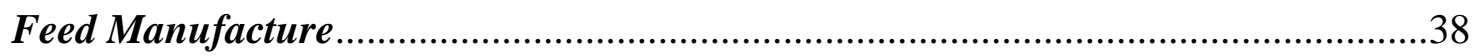

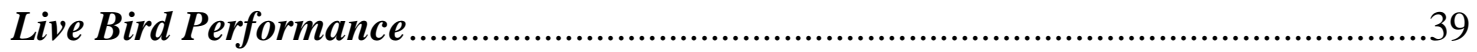

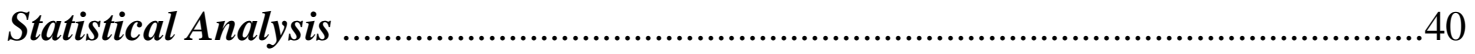

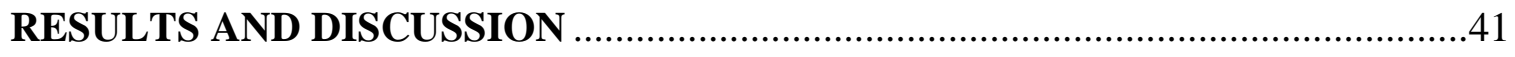

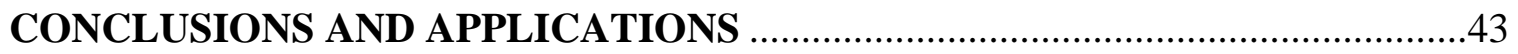

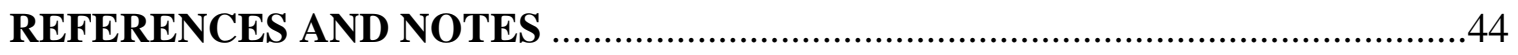

Table 1: Diet Composition of starter, grower, and finisher diets fed to Hubbard

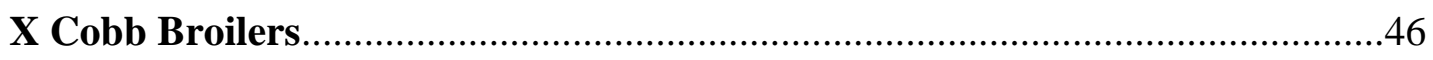

Table 2: Descriptive Feed Manufacture Data ............................................47

Table 3: Starter (D1-10) Comparisons of dietary treatments on broiler performance. .48

Table 4: Grower (D11-22) Comparisons of dietary treatments on broiler performance 
Table 5: Finisher (D23-38) Comparisons of dietary treatments on broiler performance

Table 6: Overall (D1-38) Comparisons of dietary treatments on broiler

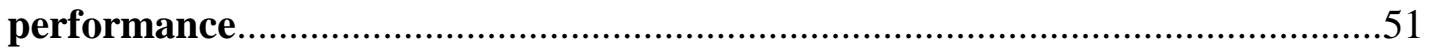

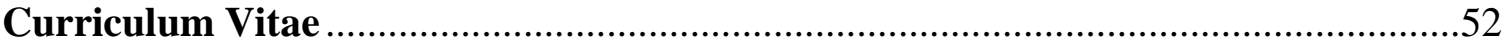

\section{LIST OF TABLES}

\section{Chapter 2}

Table 1. Negative and Positive Control Diet Formulation for Broiler Experiments One and Two

Table 2. Broiler Experiment One- Descriptive Feed Manufacture Data 30

Table 3. Broiler Experiment Two- Descriptive Feed Manufacture Data .31

Table 4. Analyzed Phytase Activity for Broiler Experiments One and Two

Table 5. Broiler Experiment One - Performance Data (Hubbard x Cobb 500 straight run broilers) .33

Table 6. Broiler Experiment Two- Performance Data (Hubbard x Cobb 500 straight run broilers) .34 


\section{Chapter 3}

Table 1: Diet Composition of starter, grower, and finisher diets fed to Hubbard X Cobb Broilers .46

Table 2: Descriptive Feed Manufacture Data 47

Table 3: Starter (D1-10) Comparisons of dietary treatments on broiler

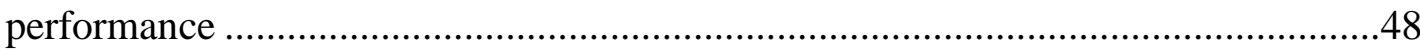

Table 4: Grower (D11-22) Comparisons of dietary treatments on broiler performance 49

Table 5: Finisher (D23-38) Comparisons of dietary treatments on broiler performance

Table 6: Overall (D1-38) Comparisons of dietary treatments on broiler

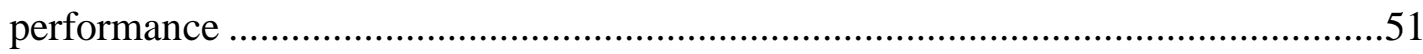




\section{KEY}

\section{Chapter 1}

1.) HAP- High Available Phosphorus

2.) GMO- Genetically Modified Organism

\section{Chapter 2}

1.) BR- Broad Range

2.) LP- Large Particle

3.) SP-Small Particle

4.) LBD- Low Bulk Density

5.) IBD-Intermediate Bulk Density

6.) HBD- High Bulk Density

7.) nPP- non phytate Phosphorus

8.) PC- Positive Control

9.) 33\% PC- 33:66 Positive Control:Negative Control

10.) NC- Negative Control

11.) PDI- Pellet Durability Index

12.) MPDI- Modified Pellet Durability Index

13.) NHPT- New Holmen Pellet Tester

14.) ASAE- American Society of Agricultural Engineers

15.) FI- Feed Intake

16.) LWG- Live Weight Gain/bird

17.) EBW- Ending Bird Weight

\section{Chapter 3}

1.) FI- Feed Intake/bird

2.) LWG- Live Weight Gain/bird

3.) EBW- Ending Bird Weight

4.) PDI- Pellet Durability Index

5.) MPDI- Modified Pellet Durability Index

6.) NHPT- New Holmen Pellet Tester

7.) ASAE- American Society of Agricultural Engineers

8.) PLT- Poultry Litter Treatment 


\section{CHAPTER 1: LITERATURE REVIEW}

\section{Poultry Production}

The United States is the largest producer of poultry in the world. Poultry products resulted in $\$ 44.1$ billion of sales in 2013 , with broiler production accounting for 70 percent ( $\$ 30.7$ billion). A total of 8.52 billion broilers were produced in 2013 in the United States resulting in 50.6 billion pounds of live weight [1]. In the United States, commercial integrators utilize vertical integration to implement product quality control. Integrators are responsible for supplying contracted growers with chicks, feed, transportation of chicks and feed, and processing the final products for sale. The contracted growers are responsible for management, facility cost, and energy cost. Grow out usually takes 38 - 42 days for small broilers until they are ready to be processed. This allows growers to have up to seven flocks per year due to the short amount of time needed. Contracted growers will be paid for each pound of live weight $(\sim 0.05 / \mathrm{lb}$.) with potential incentives for lower feed conversion compared to other contracted growers in their area.

\section{West Virginia Poultry Production}

Poultry production plays a vital role in West Virginia's economy. Poultry was the number one agricultural commodity in West Virginia with 376 million pounds of chicken valued at \$188 million produced in 2013 [1]. This resulted in West Virginia ranking as the $19^{\text {th }}$ state in the country for broiler production which is remarkable since only five counties in West Virginia produce commercial broilers. These five counties: Hardy, Grant, Hampshire, Mineral, and Pendleton are located in the Potomac Highlands region of West Virginia. Pilgrim's Pride is the largest commercial integrator in the state and second largest producer nationally. They process approximately 2 million birds per week at their Moorefield, WV complex. 


\section{Feed Manufacture}

\section{Diet Formulation/Pelleting Process}

Feed and feed manufacture account for $70-75 \%$ of the total cost of production for a commercial broiler integrator. Diet formulation is a major factor affecting production costs which leads a majority of commercial nutritionist to formulate diets based on a least cost basis while still fulfilling the broiler's nutrient requirements. This results in nutritionists using a wide variety of differing feedstuffs and by-products in diet formulation.

Another important factor affecting cost is broiler producers exclusively feed pelleted diets which further increase economics of production. On average, pelleting increases the cost of production $\$ 3-5 /$ ton of feed; however, this cost is justifiable due to increased feed intake and productive energy and decreased ingredient segregation, feed wastage, and pathogens [2-11]. The pelleting process subjects feed ingredients to high pressure, moisture, and temperature as a result of steam conditioning and extrusion through the pellet die [7,11]. These harsh conditions can potentially alter nutrient content and nutrient bioavailability $[7,11]$. The two most elucidated effects have been observed in starch and protein ingredients [7]. Since a majority of broiler feed ingredients are starch or protein, the pelleting process and pellet quality are always a concern for commercial integrators. Pellet quality is defined as the ability of a feed pellet to maintain its structural integrity from the feed mill to the feed pan [12]. Improvements seen in broiler performance associated with pelleting are undeniable, but many producers are more concerned with throughput demands than creating a high quality crumble or pellet. Current industry practices have employed low inclusions of fat in diet formulation to improve pellet quality [13]. However, past literature has demonstrated that low mixer-added fat can be detrimental to heat sensitive nutrients and mixer-added exogenous enzymes [4,10]. Utilizing a high-mixer added fat can 
improve enzyme efficacy by coating feed particles [13] and decreasing frictional heat in the pellet die [7]. Factors such as these make it important to select ingredients respective to price, bioavailability, and the effects on physical and nutritional pellet quality when performing diet formulation.

\section{Phosphorus}

Phosphorus is a mineral that is required by all life forms to maintain homeostasis. It plays a role in energy currency of cells, cellular regulatory mechanisms, and bone mineralization [14]. Bone mineralization is arguably the most important function in regards to broiler production. Bone is the largest storage form of phosphorus accounting for $85 \%$ of the body's total phosphorus [14]. Broilers grow from 50 grams to approximately $2.5 \mathrm{~kg}$ in $35-42$ days making it imperative to create a skeletal frame capable of holding these large increases in body mass.

Phosphorus can be obtained through several sources in a broiler diet. Phosphorus is found in corn and soybean meal, which compromise a majority (60-70\%) of a broilers diet. However, it is found in the storage form, phytate, which is not available for digestion and absorption in monogastrics [15] since they lack high amounts of endogenous phytase [16]. Supplementing diets with inorganic rock phosphates is utilized to meet broiler's phosphorus requirements. However, these ingredients are expensive and non-renewable [17] resulting in the need for alternatives to meet broiler's demands. One solution is to utilize genetically modified crops in an effort to make phosphorus more available. A promising example is high available phosphorus (HAP) corn. Huff et al. found HAP corn could replace $11 \%$ of total phosphorus requirements and $25 \%$ when used in combination with a phytase without affecting broiler performance or health [18]. However, HAP corn is expensive and further adds to feed manufacture costs resulting in minimal use in the 
industry. Additionally, consumer preference is to not consume genetically modified organism (GMO) derived products so this has limited their potential for several producers.

Another potential solution is the use of poultry litter biochar. Poultry litter biochar is a byproduct of poultry litter after it has been passed through a gasification chamber. This poultry litter biochar is very high in phosphorous lending its use in poultry nutrition as a replacement for diminishing inorganic rock phosphates. However, only three published studies exists using poultry litter biochar as a potential phosphorus source in poultry diets [19-21].

Although these methods have potential, the most promising solution to meet broiler phosphorus demands has been the supplementation of exogenous phytase to hydrolyze phytate of ingredients such as corn and soybean meal.

\section{Phytase}

Phytase is an enzyme capable of catalyzing hydrolysis of the phosphate ester bonds on the inositol ring of the phytate molecule [18]. As previously mentioned, phytase is found minimally in monogastrics gastrointestinal tracts, making supplementation of endogenous phytase essential for monogastrics, such as broilers. This is common practice in the poultry industry since the 1990's in an effort to increase phosphorus availability and utilization $[22,23]$ while decreasing the environmental impact [24]. Poultry litter is commonly applied to land as a cheap source of fertilizer which can become a major environmental concern due to phosphorus saturation in the soil leading to eutrophication in water ways. Eutrophication is defined as accumulation of organic matter and can result in algal blooms and depletion of available oxygen levels in water [25]. Several studies have demonstrated dietary phytase supplementation results in less phosphorus present in the litter preventing leaching of phosphorus [18, 26-33]. However, DeLaune et al., 2001 and Moore et al., 
1998 both demonstrated that even though total phosphorus content was reduced, there was a greater proportion of water-soluble phosphorus leading to easier water run-off $[34,35]$. Thus, excretion of poultry receiving phytase may have a higher than expected potential for phosphorus run-off. This is particularly important for West Virginia since the Potomac highlands and Eastern Panhandle are located within the Chesapeake Bay watershed.

Phytase can be expressed from a variety of fungal, bacterial, yeast, and plant hosts [36]. Expression host can dramatically affect how the phytase will perform in vivo. Different phytases can also differentiate on the mechanism of action for liberating phosphorus from phytate. Two classes of phytases exist: 3-phytase and 6-phytase which dephosphorylate phosphorus at the 3 or 6 position on the inositol ring of phytate, respectively. The expression host plays a major role in determining which form of phytase will be present. Most commonly, plants produce the 6-phytase and microorganisms; such as fungi, bacteria, and yeast, produce the 3-phytase [37, 38]. However, studies have shown certain serotypes of E. coli to produce 6-phytase [39] and soybeans to produce 3-phytase [40].

One common problem with phytase supplementation is determining the phytase activity. To determine phytase activity in vitro, the AOAC method 2000.12 is the "current" standard. However, this method produces results in vitro that might not accurately depict the efficacy in vivo. Loop et al. tested this hypothesis and found that the phytase with the highest activity in vitro performed the worst in vivo [41]. Gizzi et al. demonstrated that even though this method is standardized, variation exists within and among laboratories [42]. This could be due to different biochemical properties between differing phytase sources [43, 44]. This makes it imperative that commercial phytase manufacturers test both in vivo and in vitro when creating a phytase. 
Commercial phytases are commonly available in granulated or liquid forms. Granulated forms are more common due to increased mixer uniformity. However, since they are added before the pelleting process, thermal stability of the phytase becomes a major concern. Since phytase is of protein origin, the high temperatures of the pelleting process can denature phytases resulting in decreased activity. The common practice of manufacturers is to protect the phytase using a carbohydrate-lipid coating [45-47] allowing for protection of the phytase from direct heat and pressure when being steam conditioned and extruded through the pellet die [7,11]. However, Holkenburg and Braun demonstrated that an increased thickness of coating improved thermal stability, but decreased enzyme efficacy by slowing down the release of phytase in the intestinal tract [45]. Hydrolysis of phytate is believed to occur in the upper regions of the intestinal tract at a pH $>5$ which phytase is soluble, thus making it ineffective in the small intestine [48]. This effect was further demonstrated by Kwakkel et al., in which a similar coated and non-coated products were compared [49]. However, some research has demonstrated phytases derived from Escherichia coli are more active in the small intestine than phytases derived from Peniophroia lycii [50].

Liquid phytases are becoming more common in industry settings to combat thermal stability issues. Liquid phytases are commonly added with fat post-pelleting, thus are not subjected to high heat from steam conditioning. However, a complicating factor is that liquid phytase preparations are often not compatible with other liquid ingredients, such as fat [51]. Additionally, liquid fat post-pelleting has been shown to decrease pellet quality [52]. Application of liquid phytase also requires additional equipment for the manufacturer and uniformity of the application is a major concern [52]. Potential for hazardous conditions associated with the creation of aerosols within the feed mill is also of concern [53]. 
Mixer-added granulated and liquid phytase added post-pelleting both have benefits and pitfalls. Phytase supplementation has been supported by research and will continue to be utilized in the poultry industry. The major issue at hand is developing a phytase that maintains activity throughout the pelleting processing, maintains pellet quality, and ultimately maintains efficacy within the bird.

\section{Feeder Space Access}

Effects of feeder space access on commercial broiler performance are not widely reported in past literature. Trials dealing with feed restriction in past literature are achieved through reduction of the quantity of feed presented; not using a restriction of access to ad libitum feed. Deaton and Fontana both demonstrated a reduction in feed resulted in improved feed efficiency during the starter phase (d1-7) when compared to full-fed broilers $[54,55]$. However, these studies demonstrated that rate of gain and ending body weight was significantly decreased. It has been speculated that a reduction in feed would result in a reduced fat pad due to more efficient metabolism. Plavnik tested this hypothesis and demonstrated an early reduction of feed demonstrated in a reduced fat pad in broilers when reaching market weight [56]. However, similar studies have failed to demonstrate the same reduction in fat pad development resulting from early feed reduction [57, 58]. Leeson, et al. 1991 looked at the effects of feed reduction of broilers on the finisher phase (d 35-49) demonstrating a reduction in fat pad development and ending body weight as a result of feed reduction [59]. Washburn looked at the effects of feeding reduction using commercial broilers and a 1950 heritage strain of broilers through a four week or seven week reduction compared to full-fed broilers [60]. Broilers receiving four week reduction resulted in improved feed conversion compared to full-fed broilers and resulted in compensatory growth from week's four to seven when receiving feed ad libitum. Broilers receiving reduction throughout the 
seven week trial had the lowest feed conversion compared to other treatments. However, it is important to note that these birds were reared in individual cages so competition at the feed pan was not present. This may have significantly impacted the results seen in past literature. Leone and Estevez demonstrated an increased competition at the feed pan when feeder space access was restricted using six week old broilers for one hour observational periods [61]. Today's broiler genotypes have a voracious appetite and competition at the feed pan is commonly seen in a commercial setting. Research on feed restriction throughout the entire growth process using current genotypes has not been reported. This may be an important variable influencing results demonstrated in university research because feeder space access is commonly larger than seen in a commercial setting.

Phytase supplementation is an efficient tool that the poultry industry will continue to utilize to improve nutrient utilization while decreasing environmental impact. Research on different methods of production is needed to create the most efficacious product for use in the commercial industry. Research on the effects of feeder space access using current commercial broiler genotypes is not present in current literature and should be considered to make results most relevant to the commercial industry. 


\section{REFERENCES AND NOTES}

1.) USDA. Poultry-Production and Value. 2013 Summary

http://www.nass.usda.gov/Publications/Todays_Reports/reports/plva0414.pdf

Accessed March 7,2015

2.) Behnke, K.C. 1996. Feed manufacturing technology: Current issues and challenges. Animal Feed Science and Technology. 62:49-57

3.) Buchanan N.P, Moritz J.S. 2009. Main effects and interactions of varying formulation protein, fiber, and moisture on feed manufacture and pellet quality. Journal of Applied Poultry Research. 18(2):274-283

4.) Lilly, K.G.S. et al. 2011. Examining the relationships between pellet quality, broiler performance, and bird sex. Journal of Applied Poultry Research. 20(2):231-239

5.) Reece, F.N. et al. 1986. The effects of hammer mill screen size on ground corn particle size, pellet durability, and broiler performance. Journal of Poultry Science. 65(7):1257-1261

6.) Wondra, K.J. et al. 1995. Effect of particle size and pelleting on growth performance, nutrient digestibility, and stomach morphology in finishing pigs. Journal of Animal Science. 73:757-763

7.) Cutlip, S.E. et al. 2008. Effect of steam conditioning practices on pellet quality and growing broiler nutritional value. Journal of Applied Poultry Research. 17(2):249-261

8.) Hott, J.M. et al. 2008. The effect of moisture addition with a mold inhibitor on pellet quality, feed manufacture, and broiler performance. Journal of Applied Poultry Research. 17:262-271

9.) Fairchild, F. and Greer, D. 1999. Pelleting with precise mixer moisture control. Feed International Magazine. Aug: 32-36

10.) Gehring, C.K. et al. 2011. Increasing mixer-added fat reduces the electrical energy required

for pelleting and improves exogenous enzyme efficacy for broilers. Journal of Applied Poultry Research. 20:75-89

11.) Moritz, J.S. 2007. Impact of the pelleting process on dietary nutrients and supplemental enzymes. Proceedings of the Arkansas Nutrition Conference

12.) Creamer, K.R., et al. 20003. Effect of sorghum-based diets subjected to various manufacturing procedures on broiler performance. Journal of Applied Poultry Research. 12: 404-410

13.) Zimonja, O., Stevnebo, A., Svihus, B. 2007. Nutritional values of diets for broiler chickens as affected by fat source, amylose level and diet processing. Canadian Journal of Animal Science. 87: 553-562

14.) Applegate, T.J. and Angel, R. 2008. Animal sciences: phosphorus requirements for poultry. Purdue University Cooperative Extension Service, West Lafayette, IN. 
15.) Angel, R. Calcium and Phosphous requirements in broilers and laying hens. Australian Poultry Science Symposium, Sydney, South Wales. Poultry Research Foundation

16.) Nelson, T.S. 1976. The hydrolysis of phytin phosphorus by chicks and laying hens. Poult Sci. 55: $2262-2264$

17.) Grimbergen, A.H. et al. 1985. The relative availability of phosphorus in inorganic feed phosphates for young turkeys and pigs. Animal Feed Science and Technology. 13: 117-130

18.) Huff, W.E., et al. 1998. Effect of dietary phytase and high available phosphorus corn on broiler chicken performance. Poultry Sci. 77:1899-1904

19.) Akpe, M.P., et al. 1984. Bioavailbility of phosphorus in poultry litter biomass ash residue for turkeys. Poultry Sci. 63: 2100-2102

20.) Muir, F. Leach Jr., R.M., and Heinrichs, B.S. 1990. Bioavailability of phosphorus from broiler litter ash for chicks. Poultry Sci. 69:1845-1850

21.) Blake, J.P. and Hess. J.B. 2014. Poultry litter as a replacement for dicalcium phosphate in broiler diets. Journal of Applied Poultry Research. 23: 101-107

22.) Ravindran, V., et al. 1995. Phytin: Occurrence, bioavailability and implications in poultry nutrition. Poultry Avian Biology. Rev. 6: 125-143

23.) Shaw, A.L., et al. 2010. Evaluation of commercial phytase enzymes on performance and tibiabreaking strength of male broiler chicks. Journal of Applied Poultry Research. 19: 415-421

24.) Mullaney, E.J. et al. Advances in Phytase Research. Adv. Applied Microbiology. 47: 157-199

25.) Rabalias, N.N. et al. Global change and Eutrophication of coastal water. Ices Journal of Marine Science. 66: 1528-1537

26.) Shaw, A.L. et al. 2011. Assessment of an experimental phytase enzyme product on live performance, bone mineralization, and phosphorus excretion in broiler chickens. Journal of Applied Poultry Research. 20:561-566

27.) Nahm, K.H. 2002. Efficient feed nutrient utilization to reduce pollutants in poultry and swine manure. Environmental and Science Technology. 32(1): 1-16

28.) Yan, F. 2001. Phosphorus requirements of broiler chicks three to six weeks of age as influenced by phytase supplementation. Poultry Sci. 80: 455-459

29.) Broz, J.P., et al. 1994. Effects of supplemental phytase on performance and phosphorus utilization in broiler chickens fed a low phosphorus diet without addition of inorganic phosphates. British Poultry Science. 35: 273-280

30.) Kornegay, E.T., et al. 1996. Improving phytate phosphorus availability in corn and soybean meal for broilers using microbial phytase and calculation of phosphorus equivalency values for phytase. Poultry Sci. 75: 240-249

31.) Nelson, T.S., et al. 1971. Effect of supplemental on the utilization of phytate phosphorus by chicks. Journal of Nutrition. 101: 1289-1294 
32.) Simons, P.C.M., et al. 1990. Improvement of phosphorus availability by microbial phytase in broilers and pigs. British Journal of Nutrition. 64: 525-540

33.) Zhu, X.S., et al. 1990. Preparation of a low-phytate mixture and bioavailability of its phosphorus to chicks. Animal Feed Science Technology. 27: 341-351

34.) Delaune, P.B., et al. 2001. Development and validation of a phosphorus index for pastures fertilized with animal manure. Proceedings International Symposium addressing animal production and environmental issues

35.) Moore, P.A., et al. 1998. Use of high available phosphorus corn and phytase enzyme additions to broilers diets to lower phosphorus level in poultry litter. Proceedings of National Poultry Waste Management Symposium: 346-352

36.) Wodzinski, R.J. and Ullah, A.H.J. 1996. Phytase. Adv. Appl. Microbiology. 42: 263-302

37.) Reddy, N.R., et al. 1982. Phytases in legumes and cereals. Adv. Food Research. 28-1-92

38.) Nayini, N.R. and Markakis, P. 1986. Phytase. Phytic Acid: Chemistry and applications. E Graf, ed. Pilatus Press, Minneapolis, MN. 101-118

39.) Greiner, R.U., et al. 1993. Purification and characterization of two phytases for Escherichia Coli. Arch Biochem. Biophys. 303: 107-113

40.) Phillippy, B.Q., et al. 1988. Inositol phosphates in processed foods. Journal of Animal Science. 53: 496-499

41.) Loop, S.A., et al. 2012. The phytase analytical activity of pelleted diets may not adequately describe efficacy in the bird. Journal of Applied Poultry Research. 21: 492-501

42.) Gizzi, G., et al. 2008. Determination of phytase activity in feed: Interlaboratory study. Journal of AOAC INt. 91: 259-267

43.) Rodriguez, E., et al. 1999. Cloning, sequencing, and expression of an Escherichia coli acid phosphatase/phytase gene (appA2) isolated from pig colon. Biochem. Biophys. Res. Comm. 257: $117-123$

44.) Yin, Q.Q., et al. 2007. Biochemical characteristics of phytases from fungi and the transformed microorganism. Animal Feed Science Technology. 132: 341-350

45.) Klein Holkenburg, A. and Braun, J. 2001. Effect of a hydrophobic coating on phytase granulates on pelleting stability and bio-efficacy in broilers. $13^{\text {th }}$ European Symposium on Poultry Nutrition: 341 
46.) Ortega, N. Busto, M.D., Perez-Mateos, M. 1998. Stabilization of Beta-glucosidase entrapped in alginate and polyacrylamide gels towards thermal and proteolytic deactivation. Journal of Chemical Technology and Biotechnology.73:7-12

47.) Heichal-Segal, O. Rappoport, S. and Braun S. 1995. Immobilization in Alginate-Silicate SolGel matrix protects b-glucosidase against thermal and chemical denaturation. Nature Biotechnology. 13:798-800

48.) Adeola, A., Sands, J.S. 2003. Does supplemental dietary microbial phytase improve amino acid utilization? A perspective it does not. Journal of Animal Science. E-suppl. 2: E78-E85

49.) Kwakkel, R.P., et al. 2001. Bio-efficacy of two phytase formulations supplemented to a cornsoybean broiler diet. Proceedings of the $3^{\text {rd }}$ European Symposium on Feed Enzymes, The Netherlands

50.) Onyango, E.M., Bedford, M.R., and Adeola, O. 2005. Phytase activity along the digestive tract of the broiler chick: a comparative study of an Escherichia coli-derived and Peniophroia lycii phytase. Canadian Journal of Animal Science 85: 61-68

51.) Swart, S. 2006. Considerations on the use of microbial phytase. CEIFC handout. 14-15

52.) Froetschner, J. 2006. Current issues in feed manufacturing (IV) - Adding liquids to the feed after pelleting. Feed Technology Magazine. 10.8.2006: 15-16

53.) Baur, $X$, et al. 2002. Ige-mediated allergy to phytase- a new animal feed additive. Allergy, 57(10): 943-945

54.) Deaton, J.W. 1995. The effect of early feed restriction on broiler performance. Poultry Sci. $74: 1280-1286$

55.) Fontana, E.A., et al. 1992, Effect of early feed restriction on growth, feed conversion, and mortality in broiler chickens. Poultry Sci. 71: 1296-1305

56.) Plavnik, I, et al. 1986. Effect of early feed restriction in broilers. Growth performance and carcass composition. Growth. 50: 68-76

57.) Yu, M.W., et al. 1990. Growth and body composition of broiler chickens in response to different regimens of feed restriction. Poultry Sci. 69: 2074-2081

58.) Leeson, S., et al. 1991. Diet dilution and compensatory growth in broilers. Poultry Sci. 70: 867-873

59.) Leeson, S., et al. 1992. Response of broilers to feed restriction or diet dilution in the finisher period. Poultry Sci. 71: 2056-2064 
60.) Washburn, K.W. 1990. Effect of restricted feeding on fatness, efficiency, and the relationship between fatness and efficiency in broilers. 69: 502-508

61.) Leone, E.H. and Estevez, I. 2008. Space use according to the distribution of resources and level of competition. Poultry Sci. 87: 3-13 
Chapter 2: Assessing particle size distribution and bulk density of an experimental phytase on phytase retention post-pelleting and 21 day broiler performance

\author{
M.E. Lemons, A.M. Evans, and J.S. Moritz
}

Division of Animal and Nutritional Sciences, West Virginia University, Morgantown,

West Virginia, 26506-6108

Phone: 304-293-1911

Fax: 304-293-2232 
SUMMARY: Commercial broiler integrators incorporate phytase into diet formulation due to multiple benefits. These benefits result in decreased diet cost, increased broiler performance, and reduction in negative environmental impact. Two commonly used applications of phytase include mixer-added phytase, usually in the form of a granule, or post-pellet application in liquid form. Mixer-added phytase are desirable due to increased uniformity of the application and less additional equipment that is required for post-pellet application. However, mixer-added phytases must be thermally stable due to high stress conditions of temperature and friction as a result of steam conditioning and extrusion associated with pelleting. This has resulted in several modifications in commercial phytase production methods to maximize phytase efficacy. Two experiments were conducted to assess the effects of different production methods on thermal stability and broiler starter performance using a phytase of the same expression host and granulation process. All diets were formulated to meet or exceeded Agristat nutrient values with the exception of non phytate phosphorus (nPP) for the negative control and 33\% positive control. Diets were manufactured and pelleted at the West Virginia University pilot feed mill. Broiler experiment one utilized three different particle size distributions which included: broad range (BR), large particle (LP), and small particle (SP) that were added to the negative control (NC) at a target dose of 500 FTU/kg. The LP distribution demonstrated the highest phytase activity and enzyme retention post-pelleting. However, the BR distribution demonstrated the greatest benefit to d1-21 broiler performance. Broiler experiment two utilized three different bulk densities of carbohydrate-lipid encapsulation which included: low bulk density (LBD), intermediate bulk density (IBD), and high bulk density (HBD) that were added to the NC at a target dose of 500 FTU/kg. This experiment demonstrated that phytase activity increased as bulk density increased. However, the LBD had the highest enzyme retention post-pelleting and demonstrated the greatest 
d1-21 broiler performance. These experiments suggest that commercial phytase products should be of a broad range particle distribution with a low bulk density of carbohydrate-lipid encapsulation to be the most efficacious for feeding broilers.

\section{DESCRIPTION OF THE PROBLEM}

Phosphorus is an essential nutrient needed for bone health, skeletal development, membrane formation, and energy transfer [1,2]. A major portion (60-70\%) of poultry diets is corn and soybean meal which contain high amounts of phytate, a form of phosphorus that is unable to be digested and absorbed. Therefore, the incorporation of exogenous phytase to diets has been common in commercial broiler production for several decades [3,4]. Phytase supplementation results in less inorganic rock phosphates needed in broiler diets due to the improvements in utilization associated with hydrolyzing phytate bound phosphorus [5].

Commercial broilers are exclusively fed pelleted diets due to improvements in broiler performance associated with increased intake and productive energy while decreasing ingredient segregation, feed wastage, and pathogens [6-14]. The pelleting process subjects feed to high temperatures, pressure, and moisture associated with steam conditioning and extrusion from the pellet die. This can be detrimental to ingredients that are not thermally stable such as carbohydrates, vitamins, and proteins [11, 15]. Thermal stability of enzymes, such as phytase, is especially essential if the ability of the diet to meet nutrient requirements is dependent on the liberation of nutrients through enzyme function [16]. A potential solution is the use of a liquid phytase post-pelleting so thermal stability is no longer of concern. However, this can result in decreased pellet quality [17], requires additional equipment, and uniformity of the application is a major concern. 
A strategy to improve thermal stability when using a granulated mixer added phytase is to utilize a carbohydrate-lipid encapsulation [18-21]. Production of a thermal stable phytase that retains activity post-pelleting and performs well in vivo can be challenging. Loop et. al, 2012 [22] demonstrated that phytase activity (in vitro) and broiler performance (in vivo) were not directly correlated using a encapsulated, granular phytase. Thus demonstrating that it is essential to perform broiler performance experiments in addition to pelleting trials to truly determine phytase efficacy.

The objective of the current study was to assess the effects of particle size distribution and bulk density of the carbohydrate-lipid encapsulation on phytase activity retention and d1-21 broiler performance.

\section{Materials and Methods}

\section{Broiler Experiment One}

\section{Feed Manufacture}

Six dietary treatments: three standard treatments [Positive Control (PC), 33:66 PC:NC (33 \% PC), and a Negative Control (NC)] and three novel phytases added to the NC were manufactured at the West Virginia University Pilot feed mill. All diets were formulated to meet or exceed Agristat nutrient values with the exception of $\mathrm{nPP}$ for the $\mathrm{NC}$ and 33\% PC (Table 1). Novel phytases utilized in this experiment had the same expression and granulation process and were added at a target dose of $500 \mathrm{FTU} / \mathrm{kg}$ to the NC. Expression host and methods of the granulation process are proprietary and therefore are not disclosed. Novel phytases utilized in broiler experiment one differed only in particle size distribution which included: broad range [(BR) $177-841 \mu \mathrm{m}]$, large particle [(LP) 841-1190 $\mu \mathrm{m}]$, and small particle [(SP) 250-400 $\mu \mathrm{m}$ ] distributions. The PC (analyzed at $0.39 \% \mathrm{nPP}$ ) and $\mathrm{NC}$ (analyzed at $0.25 \% \mathrm{nPP}$ ) contained similar ingredient inclusions 
(Table 1). Once pelleted, PC and NC treatments were mixed to create a 33:66 PC:NC treatment (analyzed at $0.32 \% \mathrm{nPP}$ ). Treatments containing phytase were added to $2.27 \mathrm{~kg}$ of ground corn and $3.22 \mathrm{~kg}$ of salt and mixed for 10 minutes using a small paddle mixer [23] before addition to the total batch. This was performed in an effort to ensure the small inclusion of phytase granule would be incorporated in the total batch due to residual feed left in conveyance of the auger leading to the mixer. Five $920 \mathrm{~kg} \mathrm{NC}$ batches and one $920 \mathrm{~kg}$ PC batch were mixed using a 1-ton vertical screw East Automation Inc. mixer [24]. Diets were then steam conditioned using a 1.31 x $0.31 \mathrm{~m}$ short-term (10s) California Pellet Mill conditioner at $85{ }^{\circ} \mathrm{C}$ and extruded through a 5 x $38 \mathrm{~mm}$ pellet die driven by a 40 horsepower California Pellet Mill [25]. Pelleted diets were ground via roller mill to mash to eliminate feed form effects. Production rate was determined by measuring pellet volume post extrusion for 60 second sampling periods. Hot pellet temperature was determined from collecting pellets post extrusion using a sealed insulated container and probing for 30 seconds with a digital thermometer [26]. Pellet mill amperage was determined from an average of the lowest and highest values during each pelleting run using a calibrated amperage meter. Pellet Durability Index (PDI) and Modified Pellet Durability Index (MPDI) were performed using a Pfost tumbler box [27] and the New Holmen Pellet Tester (NHPT) [28] were used to determine pellet durability 24 hours post-pelleting (Table 2). Percent pellets were determined by sieving $22.68 \mathrm{~kg}$ of feed through an American Society of Agricultural Engineers (ASAE) \#5 sieve and weighing retained feed. Pellets were defined as feed retained on the ASAE\# 5 sieve with feed passing through being considered fines. Feed particle size and particle standard deviation were determined using a 100 g representative sample passed through a RO-TAP RX-29 for a 10 minute processing period [29]. Descriptive data for the composition of feed presented to broilers during broiler trial one are presented in Table 2. Unconditioned mash and cooled pellet 
samples were sent to a commercial laboratory [30] to determine phytase activity using the AOAC 2000.12 standardized method [31] (Table 4).

\section{Live Bird Performance}

Treatment structure included six dietary treatments arranged in a randomized complete block design. A total of 384 Hubbard x Cobb straight run broiler chicks were obtained from a commercial hatchery [32] and reared in raised wire cages from d1-21. Each treatment was replicated eight times to create a total of 48 pens with eight broilers/pen. Birds were weighed as a pen on days seven and 14 and individually weighed on d21. Feed intake throughout the experiment was calculated on $\mathrm{d} 21$. Variables measured included pen feed intake (FI), live weight gain/ bird (LWG), ending bird weight (EBW), mortality corrected FCR, and percent mortality. Left tibiae were excised on d21 and were defatted with petroleum ether using a Soxhlet apparatus [33] prior to ashing in a muffle furnace [34]. Broilers were reared using environmental recommendations obtained from Cobb-Vantress [35]. All methodologies were compliant with protocol (12-0408) approved by the West Virginia University Animal Care and Use Committee.

\section{Broiler Experiment Two}

\section{Feed Manufacture}

Six dietary treatments: three standard treatments [Positive Control (PC), 33:66 PC:NC (33\%PC), and a Negative Control (NC)] and three novel phytases added to the NC were manufactured at the West Virginia University Pilot feed mill. Diets were manufactured using similar methodologies described in broiler experiment one with the exception that pellets were ground via roller mill to produce a large crumble in an effort to improve rate of gain. Diet formulations utilized in broiler experiment one were utilized in broiler experiment two with different analyzed nPP values 
attributed to differences in ingredient sourcing. Positive Control was analyzed to contain $0.41 \%$ nPP, $33 \%$ PC contained $0.33 \%$ nPP, and the NC contained $0.23 \%$ nPP. Novel phytases utilized in broiler trial two had the same expression and granulation process utilized in broiler trial one and were added at a target dose of $500 \mathrm{FTU} / \mathrm{kg}$ to the NC. Novel phytases differed in bulk density of the lipid encapsulation utilized to protect the phytase granule. These bulk densities included: low bulk density (LBD), intermediate bulk density (IBD), and high bulk density (HBD). Bulk density production methods are proprietary, therefore descriptive data is not disclosed in this report. Sampling and variables measured were the same as utilized in broiler experiment one. Descriptive data for the composition of feed presented to broilers in broiler experiment two can be found in Table 3.

\section{Live Bird Performance}

The same methodology and treatment structure utilized in broiler experiment one were implemented in broiler experiment two. The same variables utilized in broiler experiment one were collected with the exception that birds were individually weighed on day 14 and 21 in broiler experiment two. All birds were reared using environmental recommendations obtained from Cobb-Vantress [35]. All methodologies were compliant with protocol (12-0408) approved by the West Virginia University Animal Care and Use Committee.

\section{Statistical Analysis}

Variables were analyzed in a randomized complete block design using one-way ANOVA. Treatments were further analyzed using Fisher's LSD multiple comparison test. The experimental unit was one pen containing 8 straight run broilers. Blocking criterion consisted of room and location of the raised wire cage. Data were analyzed using the GLM procedure of SAS [36]. Alpha 
was designated as 0.05 and letter superscripts were used to denote differences among treatment means.

\section{RESULTS AND DISCUSSION}

\section{Broiler Trial One}

\section{Phytase Retention}

Analyzed phytase activity and retention post-pelleting descriptive data are presented in Table 4. The LP distribution resulted in the greatest activity and retention. It is important to note that the pelleted sample had greater activity than the unconditioned mash which is unexpected. The authors would speculate this is due to variability in the AOAC 2000.12 assay. The AOAC 2000.12 is the current "standard" assay to determine phytase activity but results per se have been shown to be variable; having low repeatability and reproducibility among different laboratories [37]. The potential to compound error associated with retained activity calculations should be considered when conducting in vitro experiments. The BR and SP distributions demonstrated similar phytase activity with the BR resulting in a higher phytase retention percentage.

\section{Broiler Performance}

Performance data for broiler trial one are presented in Table 5. The PC resulted in the greatest performance for all metrics as expected $(\mathrm{P}<0.05)$. The $\mathrm{BR}$ distribution resulted in the largest LWG and EBW when compared to the other phytase particle size distributions $(\mathrm{P}<0.0001)$ with all phytase treatments performing better than the $\mathrm{NC}$ and $33 \% \mathrm{PC}$. All particle size distributions resulted in a statistically similar FCR with the SP distribution demonstrating the lowest numerical FCR while also being statistically similar to the PC. However, the LP distribution was statistically similar to the NC. All particle size distributions were statistically 
similar for day seven and 14 pen weight, while being statistically similar to the PC for day seven weight. Pen FI was statistically similar for the LP and SP distribution with the BR distribution statistically consuming more feed $(\mathrm{P}<0.0001)$.

Tibiae ash percent was statistically similar between all phytase particle size distributions with $\mathrm{PC}$ resulting in largest tibiae ash $(\mathrm{P}<0.0001)$. Similar results were seen for tibiae ash $(\mathrm{g} / \mathrm{kg}$ of body weight $(\mathrm{P}<0.0001)$. The BR distribution demonstrated the greatest tibiae ash (mg/chick) when compared to the other phytase treatments $(\mathrm{P}<0.0001)$ while not performing as well as the PC.

Research dealing with particle size distributions of the phytase granule is not present in past literature. Particle size of phytase may be an important factor as chicks only consume <30 grams of feed daily in the first week [35]. Reduction in particle size has demonstrated an improvement in nutrient digestibility due to improvements in surface area and access of digestive enzymes [38]. One could speculate that smaller particle size of the phytase would result in more opportunity for consumption of phytase improving phosphorus digestibility. All phytase particle size distributions utilized in broiler experiment one overcame the deficiency in nPP compared to the NC demonstrating phosphorus sparing effects. However, phytase supplemented treatments did not result in improvements in broiler performance greater than demonstrated in the PC diet. Authors would speculate this a result of using a 500 FTU/kg dose. This 500 FTU/kg is a common dose applied in a commercial setting that has demonstrated a $0.1 \%$ sparing effect of phosphorus [39-40]. Nelson et al., 1971 demonstrated an $88.9 \%$ disappearance in phytate-P using a 3800 FTU/kg dose compared to a 38.9\% disappearance seen a 950 FTU/kg dose [41]. However, there was a notable lag in interest of phytase research from the time of this trial until the early 1990's due to commercialization of phytase as a feed additive [42]. A new area of research is the use of "super-dosing" of phytase resulting in improvements in performance compared to PC treatments in addition to the phosphorus sparing effect commonly demonstrated. Shirley and Edwards, 2003 demonstrated a $95 \%$ disappearance of phytate-P using doses of 12,000 FTU/kg compared to $42 \%$ seen in 93 FTU/kg diets [43]. Super dosing effects have thoroughly been studied in current literature and consistently demonstrate improvements in broiler performance using marginal diets 
[41-46]. However, the mechanism is still not quite clear. Coweison et al., 2011 has speculated three potential mechanisms: 1.) More liberated phosphate or restoration of P/CA proportionate release, 2.) Less residual phytate antinutritional effects due to more soluble esters, and 3.) Generation of myo-inositol with vitamin-like/lipotropic effects [42]. Perhaps if we employed a higher phytase dose we would have demonstrated more pronounced improvements in broiler performance in addition to the phytase sparing effects. These results of broiler experiment one agree with the findings of Loop et al., 2012 demonstrating phytase activity (in vitro) and broiler performance (in vivo) were not directly correlated [22]. Findings of the current experiment suggest that commercial granulated phytase products should be of a broad range particle size distribution to maximize feeding efficacy.

\section{Broiler Experiment Two}

\section{Phytase Retention}

Analyzed phytase activity and retention post-pelleting descriptive data are presented in Table 4. The HBD demonstrated the greatest activity, but also demonstrated the lowest retention rate post-pelleting. The IBD and LBD demonstrated similar phytase activity and retention postpelleting.

\section{Broiler Performance}

Performance data for broiler experiment two are presented in Table 6. The PC resulted in the greatest performance for all metrics as expected $(\mathrm{P}<0.05)$. The LBD treatment demonstrated the highest numerical LWG compared to the other phytase treatments with IBD performing statistically similar to the LBD treatment. The HBD was statistically similar to the IBD while being inferior to the LBD $(\mathrm{P}<0.05)$. A similar effect was demonstrated for EBW. All treatments had greater performance than seen in the NC with only the LBD performing statistically similar to the $33 \% \mathrm{PC}$ in regards to LWG and EBW. All bulk density treatments demonstrated statistically 
similar FCR to the PC. A similar effect was demonstrated for day seven pen weight. Day 14 bird weight demonstrated statically similar weights between bulk density treatments while being inferior to the PC. Pen FI was statistically similar demonstrating bulk density did not affect consumption.

Tibiae ash percent demonstrated the LBD had the largest percent ash with HBD being intermediate to both the LBD and IBD treatments $(\mathrm{P}<0.0001)$. The LBD treatment demonstrated the largest tibiae ash (mg/chick) with the IBD and HBD treatments performing statistically similar $(\mathrm{P}<0.0001)$. Bulk densities treatments were inferior to the 33\% PC and PC in regards to tibiae ash (mg/chick) and tibiae ash (g/kg of body weight). All bulk density treatments performed statistically similar to one another for tibiae ash (g/kg of body weight). However, all bulk densities performed statistically similar to the $\mathrm{NC}$ in regards to tibiae ash ( $\mathrm{g} / \mathrm{kg}$ of body weight).

The HBD demonstrated the greatest phytase activity but demonstrated a decrease in performance compared to the LBD and IBD. However, the LBD and IBD demonstrated similar phytase retention and activity which correlated to statistically similar broiler performance. The results demonstrated by the HBD treatment agree with the findings of Loop et al., 2012 [22]. Holkenburg and Braun, 2001 studied the effects of encapsulation coating thickness and demonstrated that increased coating improved thermal stability but decreased enzyme efficacy [20]. Authors speculated this was due to delayed hydrolysis which must take place in the upper regions of the gastrointestinal tract and a pH at which phytase is soluble. These speculations were supported by Kwakkel et al., 2001 in which similar coated and non-coated products were compared [21]. These findings demonstrate that coating of enzymes is not without risk, as bioavailability can be reduced significantly. 
One interesting aspect of the current study is that a 100 gram improvement in EBW and LWG were demonstrated in the PC compared to the diets supplemented with phytase while FCR was statistically similar between these treatments. Authors would speculate this is due to improvements associated with providing a large crumble instead of mash as presented in broiler experiment one. Perhaps the improvement associated with feed form helped combat some of the antinutritional effects of deficient nPP diets. However, it is important to note that all treatments particle size was within $50 \mu \mathrm{m}$, so all treatments were relative and it may have been more of a synergistic effect of phosphorus sparing and improvements in feed form. Also, as previously mentioned in broiler experiment one results, perhaps our dosage of $500 \mathrm{FTU} / \mathrm{kg}$ was too low to observe improvements in broiler performance relative to the PC treatment. The results of this experiment suggest commercial granulated phytase products should incorporate an encapsulation of low bulk density to maximize feeding efficacy.

\section{CONCLUSIONS AND APPLICATIONS}

1.) Commercial phytase testing should utilize in vivo in addition to in vitro experiments to best and most comprehensively determine phytase efficacy.

2.) Commercial granulated phytase products should be of a broad range particle size distribution to maximize feeding efficacy.

3.) Commercial granulated phytase products should incorporate an encapsulation of low bulk density to maximize feeding efficacy. 


\section{REFERENCES AND NOTES}

1.) Applegate, T. J., and R. Angel. 2008. Animal sciences: phosphorus requirements for poultry. Purdue University Cooperative Extension Service, West Lafayette, IN.

2.) NRC. 1994. Nutrient Requirements of Poultry. (th eev. Ed. Natl.Acad Press, Washington, DC.

3.) Amerah, A.M., Gilbert, C., Simmins, P.H., and Ravindran, V. 2011. Infleunce of feed processing on the efficacy of exogenous enzymes in broiler diets. World Poultry Science Journal. 61(1):29-46

4.) Bedford, M.R. 2000. Exogenous enzymes in monogastric nutrition-their current value and future benefits. Animal Feed Science and Technology. 86:1-13

5.) Huff, W.E., et al. 1998. Effect of Dietary Phytase and High Available Phosphorus Corn on Broiler Chicken Performance. Poultry Sci. 77:1899-1904

6.)Behnke, K.C. 1996. Feed manufacturing technology: Current issues and challenges. Animal Feed Science and Technology. 62:49-57

7.) Buchanan N.P, Moritz J.S. 2009. Main effects and interactions of varying formulation protein, fiber, and moisture on feed manufacture and pellet quality. Journal of Applied Poultry Research. 18(2):274-283

8.) Lilly, K.G.S. et al. 2011. Examining the relationships between pellet quality, broiler performance, and bird sex. Journal of Applied Poultry Research. 20(2):231-239

9.) Reece, F.N. et al. 1986. The effects of hammer mill screen size on ground corn particle size, pellet durability, and broiler performance. Journal of Poultry Science. 65(7):1257-1261

10.) Wondra, K.J. et al. 1995. Effect of particle size and pelleting on growth performance, nutrient digestibility, and stomach morphology in finishing pigs. Journal of Animal Science. 73:757-763

11.) Cutlip, S.E. et al. 2008. Effect of steam conditioning practices on pellet quality and growing broiler nutritional value. Journal of Applied Poultry Research. 17(2):249-261

12.) Hott, J.M. et al. 2008. The effect of moisture addition with a mold inhibitor on pellet quality, feed manufacture, and broiler performance. Journal of Applied Poultry Research. 17:262-271

13.) Fairchild, F. and Greer, D. 1999. Pelleting with precise mixer moisture control. Feed International Magazine. Aug: 32-36

14.) Gehring, C.K. et al. 2011. Increasing mixer-added fat reduces the electrical energy required for pelleting and improves exogenous enzyme efficacy for broilers. Journal of Applied Poultry Research. 20:75-89

15.) Moritz, J.S. 2007. Impact of the pelleting process on dietary nutrients and supplemental enzymes. Proceedings of the Arkansas Nutrition Conference

16.) Angel, R., et al. 2005. Effects of dietary phosphorus, phytase, and 25-hydroxycholecalciferol on performance of broiler chickens grown in floor pens. Poultry Sci. 84:1031-1044 
17.) Froetschner, J. 2006. Current issues in feed manufacturing (IV) - Adding liquids to the feed after pelleting. Feed Technology Magazine. 10.8.2006: 15-16

18.) Ortega, N. Busto, M.D., Perez-Mateos, M. 1998. Stabilization of Beta-glucosidase entrapped in alginate and polyacrylamide gels towards thermal and proteolytic deactivation. Journal of Chemical Technology and Biotechnology.73:7-12

19.) Heichal-Segal, O. Rappoport, S. and Braun S. 1995. Immobilization in Alginate-Silicate SolGel matrix protects b-glucosidase against thermal and chemical denaturation. Nature Biotechnology. 13:798-800

20.) Holkenburg, K., Braun, J. 2001. Effect of a hydrophobic coating on phytase granulates on pelleting stability and bio-efficacy in broilers. $13^{\text {th }}$ European Symposium on Poultry Nutrition:341

21.) Kwakkel, R.P , et al. 2001. Bio-efficacy of two phytase formulations supplemented to a cornsoybean broiler diet. Proceedings of the $3^{\text {rd }}$ Europen Symposium on Feed Enzymes, The Netherlands

22.) Loop, S.A., et al. 2012. The phytase analytical activity of pelleted diets may not adequately describe efficacy in the bird. Journal of Applied Poultry Research, 21:402-501

23.) Hobart paddle mixer (model 4146) Hobart Corp., Troy, OH

24.) MFP Vertical Mixer, Easy Automation Inc., Welcome, MN.

25.) Master Model Pellet Mill, California Pellet Mills Company, Crawfordsville, IN.

26.)51-II Thermometer, Fluke Corporation, Everett, WA

27.) American Society for Agricultural Engineers. 1983. Methods for determining and expressing fineness of feed materials by sieving. Page 325 in American Society of Agricultural Engineers Standard S 319. Am. Soc. Agric. Eng. Yearbook Standards, Am. Soc. Am. Eng., St. Joseph, MI. Pellet durability index was determined by sifting $500 \mathrm{~g}$ of pellets from a treatment through a No. 5 American Society for Testing and Materials (ASTM) screen before being deposited into a Pfost tumbler. The sifted pellets were then tumbled in the container, dimensions $5 \times 12 \times 12$ in., with a $2 \times 9$ in. plate fixed diagonally along the $12 \times 12 \mathrm{in}$. side, for approximately $10 \mathrm{~min}$ at $50 \mathrm{rpm}$. The sample was then sifted again through the No. 5 (ASTM) mm screen, weighed, and the percentage of pellets was calculated by dividing the weight of pellets after tumbling by the weight of pellets before tumbling and then multiplying that value by 100. Modified pellet durability index was similarly measured, with the exception of the addition of five, 13-mm hexagonal bolts to the 500 $\mathrm{g}$ of sample in the tumbler. Both analyses are meant to simulate the deleterious effects of transferring and handling the pellets

28.) Pellet quality was assessed one day following production using the New Holmen Portable Pellet Durability Tester, Lignotech USA, INC., Rothschild, WI. $100 \mathrm{~g}$ of pellets were sifted through No. 5 American Society for Testing and Materials (ASTM) screen and placed in holding chamber, blown for 30 seconds by a jet of air, then weighed, giving a direct read of pellet durability. Fines are removed during the blowing process.

29.) RO-Tap RX-29, W.S. Tyler, Mentor, OH

30.) Eurofins Analytical Lab. Des Moines, IA 
31.) AOAC. 2000. Method 2000.12 Phytase activity in feed: Calorimetric enzymatic method. Official Methods of Analysis of AOAC International. 17 ${ }^{\text {th }}$ edition. Assoc. Off. Anal. Chem., Arlington, VA

32.) Pilgrim's Pride Hatchery. Moorefield, WV

33.) AOAC. Method 920.39. Fat (Crude) or Ether Extract in animal feed. 15th edition. Assoc. Off. Anal. Chem., Arlington VA. Tibia were dried at $105{ }^{\circ} \mathrm{C}$ for 72 hours in drying oven, placed in Whatman 41 filter paper and ran through Soxhlet apparatus using petroleum ether for 18 hours.

34.) AOAC. Method 942.05. Ash of animal feed. $15^{\text {th }}$ edition. Assoc. Off. Anal. Chem., Arlington, VA. Defatted tibiae were placed in crucibles and placed in a muffle furnace for 16 hours at 600 ${ }^{\circ} \mathrm{C}$.

35.) Cobb-Vantress, Siloam Springs, AR. 2008. Cobb 500 Broiler Performance and Nutrition Supplement.

36.) SAS Institute. 2000. The SAS System for Windows 2000. Release 8.1. SAS Inst. Inc., Cary, NC.

37.) Gizzi, G., et al. 2008. Determination of phytase activity in feed: Interlaboratory study. Journal of AOAC Int. 91:259-267

38.) Jurgens, M.H. 1993. Methods of feedstuff preparation. Pages 200-225 in Animal Feeding and Nutrition. $7^{\text {th }}$ edition. Kendall/Hunt Publishing Co. Dubuque, IA

39.) Farzinpour, A., A. Karimi, and A. S. Ahmadi. 2011. Effects of dietary phytase and different levels of non-phytate phosphorus on serum minerals and biochemical parameters in broiler chickens. J. Anim. Vet. Adv. 10: 1317 - 1321.

40.) Jones, C. K., M. D. Tokach, B. W. Ratliff, N. L. Horn, S. S. Dritz, R. D. Goodband, J. M. DeRouchey, and J. L. Nelssen. Efficacy of different commercial phytase sources and development of a phosphorus release curve. Nursery Pig Nutrit. And Manag. 106 - 121

41.) Nelson, T.S., et al. 1971. Effect of supplemental phytase on the utilization of phytate phosphorus by chicks. Jounral of Nutrition. 101: 1289-1294

42.) Cowieson, A.J., Wilcock, P. and Bedford, M.R. 2011. Super-dosing effects of phytase in poultry and other monogastrics. World's Poultry Science Journal. 67:225-235

43.) Shirley, R.B. and Edwards Jr. H.M. 2003. Graded levels of phytase past industry standards improves broiler performance. Poultry Science. 82: 671-680

44.) Augspurger, N.R. and Baker, D.H. 2004. High Dietary phytase levels maximize phytatephosphorus utilization but do not affect protein utilization in chicks fed phosphorus-or amino aciddeficient diets. Journal of Animal Science. 82: 1100-1107

45.) Coweison, A.J., Acamovic, and Bedford,M.R. 2006. Phytic acid and phytase: implications for protein utilization by poultry. Poultry Science. 85: 878-885

46.) Prigozliev, V, et al. 2007. Diets containing Escherichia coli-derived phytase on young chickens and turkeys: effects on performance, Metabolizable energy and endogenous secretions and intestinal morphology. Poultry Science. 86: 705-713 
Table 1. Negative and Positive Control Diet Formulation for Broiler Experiments One and Two

\begin{tabular}{|c|c|c|c|c|}
\hline & \multicolumn{2}{|c|}{ Negative Control (NC) } & \multicolumn{2}{|c|}{ Positive Control (PC) } \\
\hline Ingredient & \multicolumn{2}{|c|}{ Inclusion, \% } & \multicolumn{2}{|c|}{ Inclusion, \% } \\
\hline Corn & \multicolumn{2}{|c|}{62.20} & \multicolumn{2}{|c|}{62.17} \\
\hline Soybean Meal (48\%) & \multicolumn{2}{|c|}{32.26} & \multicolumn{2}{|c|}{32.26} \\
\hline Soybean Oil & \multicolumn{2}{|c|}{1.85} & \multicolumn{2}{|c|}{1.86} \\
\hline Limestone & \multicolumn{2}{|c|}{1.63} & \multicolumn{2}{|c|}{0.67} \\
\hline Defluorinated Phosphate & \multicolumn{2}{|c|}{0.68} & \multicolumn{2}{|c|}{1.80} \\
\hline Sodium Chloride & \multicolumn{2}{|c|}{0.39} & \multicolumn{2}{|c|}{0.25} \\
\hline Methionine & \multicolumn{2}{|c|}{0.33} & \multicolumn{2}{|c|}{0.33} \\
\hline Lysine & \multicolumn{2}{|c|}{0.26} & \multicolumn{2}{|c|}{0.26} \\
\hline Vitamin/Trace Mineral Premix ${ }^{1}$ & \multicolumn{2}{|c|}{0.25} & \multicolumn{2}{|c|}{0.25} \\
\hline Threonine & \multicolumn{2}{|c|}{0.10} & \multicolumn{2}{|c|}{0.10} \\
\hline Chlorotetracycline ${ }^{2}$ & \multicolumn{2}{|c|}{0.05} & \multicolumn{2}{|c|}{0.05} \\
\hline \multicolumn{5}{|c|}{ Analyzed Values ${ }^{3}$} \\
\hline Broiler Experiment & 1 & 2 & 1 & 2 \\
\hline Total Calcium (\%) & 0.81 & 0.95 & 0.89 & 0.93 \\
\hline Total Phosphorus (\%) & 0.46 & 0.44 & 0.62 & 0.65 \\
\hline Phytic Acid (\%) & 0.76 & 0.75 & 0.81 & 0.85 \\
\hline \multicolumn{5}{|c|}{ Calculated Values } \\
\hline Non Phytate Phosphorus \% (nPP) ${ }^{4}$ & 0.25 & 0.23 & 0.39 & 0.41 \\
\hline
\end{tabular}

${ }^{1}$ Supplied per kg of diet: manganese, $0.02 \%$; zinc $0.02 \%$; iron, $0.01 \%$; copper, $0.0025 \%$; iodine, $0.0003 \%$; selenium, $0.00003 \%$; folic acid, 0.69mg; choline, 386mg' riboflavin, 6.61 mg; biotin, $0.03 \mathrm{mg}$; vitamin B6, 1.38mg; niacin, 27.56mg; pantothenic acid, $6.61 \mathrm{mg}$; thiamine, 2.20mg; manadione, $0.83 \mathrm{mg}$; vitamin B12, 0.01mg; vitamin E, $16.53 \mathrm{IU}$; vitamin D3, $2133 \mathrm{ICU}$; vitamin A, 7716 IU

${ }^{2}$ Chlorotetracycline $110 \mathrm{~g} / \mathrm{kg}$ (55g/1,000 kg inclusion; Zoetis Inc. Florham Park, NJ), for an increased rate of live weight gain and improved FCR

${ }^{3}$ Obtained from Eurofins Analytical Lab, Des Moines, Iowa

${ }^{4}$ Non Phytate Phosphorus calculated using the following equation [Total Phosphorus - $(0.282 \mathrm{x}$ Phytic Acid $)$ ] 
Table 2. Broiler Experiment One- Descriptive Feed Manufacture Data

\begin{tabular}{|c|c|c|c|c|c|c|c|c|c|}
\hline Treatment & $\begin{array}{c}\text { Conditioning } \\
\text { Temperature } \\
\left({ }^{\circ} \mathrm{C}\right)\end{array}$ & $\begin{array}{c}\text { Production } \\
\text { Rate (tonne/hr) }\end{array}$ & $\begin{array}{c}\text { Hot Pellet } \\
\text { Temperature } \\
\left({ }^{\circ} \mathrm{C}\right)\end{array}$ & $\begin{array}{l}\text { Pellet Mill } \\
\text { Amperage } \\
\text { Usage (A) }\end{array}$ & $\begin{array}{c}\text { Average NHPT } \\
\text { (\%) }\end{array}$ & $\begin{array}{c}\text { Average } \text { PDI }^{2} \\
(\%)\end{array}$ & $\begin{array}{c}\text { Average } \mathrm{MPDI}^{3} \\
\text { (\%) }\end{array}$ & $\begin{array}{c}\text { Percent Pellets } \\
\text { (\%) }\end{array}$ & $\begin{array}{c}\text { Average } \\
\text { Particle Size } \\
(\mu \mathrm{m}) \pm S D\end{array}$ \\
\hline $\begin{array}{c}\text { 100\% Positive } \\
\text { Control }\end{array}$ & 85 & 0.8290 & 84.22 & 19.0 & 87.5 & 91.51 & 87.95 & 93.63 & $812 \pm 1.69$ \\
\hline $\begin{array}{c}\text { 33\% Positive } \\
\text { Control }\end{array}$ & 85 & 0.6586 & 86.78 & 19.3 & 87.1 & 91.93 & 88.81 & 93.90 & $758 \pm 1.72$ \\
\hline $\begin{array}{c}100 \% \text { Negative } \\
\text { Control }\end{array}$ & 85 & 0.9428 & 85.17 & 19.2 & 92.4 & 94.49 & 92.20 & 94.39 & $790 \pm 1.62$ \\
\hline $\begin{array}{c}\text { Phytase BR } \\
(177-841 \mu \mathrm{m})\end{array}$ & 85 & 0.9591 & 85.50 & 19.2 & 90.5 & 93.27 & 90.87 & 92.71 & $746 \pm 1.71$ \\
\hline $\begin{array}{c}\text { Phytase LP } \\
(841-1190 \mu \mathrm{m})\end{array}$ & 85 & 0.9487 & 87.22 & 19.5 & 91.7 & 92.65 & 90.43 & 94.58 & $775 \pm 1.73$ \\
\hline $\begin{array}{c}\text { Phytase SP } \\
(250-400 \mu \mathrm{m})\end{array}$ & 85 & 0.9123 & 87.00 & 19.2 & 92.2 & 92.18 & 91.45 & 95.47 & $752 \pm 1.73$ \\
\hline
\end{tabular}

${ }^{1}$ New Holman Pellet Tester

2 Pellet Durability Index (Pfost tumbler)

${ }^{3}$ Modified Pellet Durability Index (Pfost tumbler)

${ }^{4} 22.68 \mathrm{~kg}$ sifted through ASAE \# 5 sieve

5 Pellets were ground using roller mill; Particle Size determined using RO-TAP RX-29 for 10 minutes 
Table 3. Broiler Experiment Two- Descriptive Feed Manufacture Data

\begin{tabular}{|c|c|c|c|c|c|c|c|c|c|}
\hline Treatment & $\begin{array}{c}\text { Conditioning } \\
\text { Temperature } \\
\left({ }^{\circ} \mathrm{C}\right)\end{array}$ & $\begin{array}{l}\text { Production Rate } \\
\text { (tonne/hr) }\end{array}$ & $\begin{array}{c}\text { Hot Pellet } \\
\text { Temperature } \\
\left({ }^{\circ} \mathrm{C}\right)\end{array}$ & $\begin{array}{l}\text { Pellet Mill } \\
\text { Amperage } \\
\text { Usage } \\
\text { (A) }\end{array}$ & $\begin{array}{c}\text { Average } \\
\text { NHPT }^{1} \\
(\%)\end{array}$ & $\begin{array}{c}\text { Average } \mathrm{PDI}^{2} \\
(\%)\end{array}$ & $\begin{array}{c}\text { Average } \\
\text { MPDI }^{3} \\
(\%)\end{array}$ & $\begin{array}{c}\text { Percent } \\
\text { Pellets } 4 \\
(\%)\end{array}$ & $\begin{array}{c}\text { Average } \\
\text { Particle Size }^{5} \\
(\mu \mathrm{m}) \pm S D\end{array}$ \\
\hline $\begin{array}{c}\text { 100\% Positive } \\
\text { Control }\end{array}$ & 85 & 0.7422 & 82.72 & 18.8 & 83.3 & 89.04 & 84.25 & 92.93 & $1855 \pm 1.95$ \\
\hline $\begin{array}{c}33 \% \text { Positive } \\
\text { Control }\end{array}$ & 85 & 0.7952 & 83.22 & 19.1 & 84.3 & 90.08 & 86.30 & 93.60 & $1839 \pm 1.92$ \\
\hline $\begin{array}{c}100 \% \\
\text { Negative } \\
\text { Control }\end{array}$ & 85 & 0.7816 & 83.78 & 19.5 & 90.5 & 93.23 & 90.34 & 95.29 & $1873 \pm 1.79$ \\
\hline Phytase LBD & 85 & 0.7757 & 82.44 & 19.2 & 87.0 & 91.27 & 88.40 & 93.97 & $1869 \pm 1.94$ \\
\hline Phytase IBD & 85 & 0.7735 & 83.16 & 19.5 & 89.1 & 92.10 & 88.93 & 94.85 & $1869 \pm 1.92$ \\
\hline Phytase HBD & 85 & 0.7950 & 83.61 & 19.4 & 83.8 & 90.06 & 86.46 & 93.54 & $1906 \pm 1.90$ \\
\hline
\end{tabular}

${ }^{1}$ New Holman Pellet Tester

2 Pellet Durability Index (Pfost tumbler)

${ }^{3}$ Modified Pellet Durability Index (Pfost tumbler)

${ }^{4} 22.68 \mathrm{~kg}$ sifted through ASAE \# 5 sieve

5 Pellets were ground using roller mill; Particle Size determined using RO-TAP RX-29 for 10 minutes 
Table 4. Analyzed Phytase Activity for Broiler Experiments One and Two

\begin{tabular}{|c|c|c|c|c|c|}
\hline $\begin{array}{l}\text { Treatment (Broiler } \\
\text { Experiment) }\end{array}$ & $\begin{array}{c}\text { Conditioning } \\
\text { Temperature } \\
\left({ }^{\circ} \mathrm{C}\right)\end{array}$ & Sample Form & $\begin{array}{l}\text { Analyzed Phytase } \\
\text { Activity }^{1} \text { (FTU/kg) }\end{array}$ & $\begin{array}{c}\text { Enzyme } \\
\text { Retention }{ }^{2} \\
(\%)\end{array}$ & $\begin{array}{c}\text { Calculated nPP3 } \\
(\%)\end{array}$ \\
\hline \multirow{2}{*}{$\begin{array}{c}\text { Phytase BR (1) } \\
(177-841 \mu \mathrm{m})\end{array}$} & \multirow[t]{2}{*}{85} & Unconditioned Mash & 300 & \multirow[t]{2}{*}{56.67} & \multirow[t]{2}{*}{0.23} \\
\hline & & Pellet & 170 & & \\
\hline \multirow{2}{*}{$\begin{array}{l}\text { Phytase LP(1) } \\
(841-1190 \mu \mathrm{m})\end{array}$} & \multirow{2}{*}{85} & Unconditioned Mash & 200 & \multirow{2}{*}{120.00} & \multirow{2}{*}{0.22} \\
\hline & & Pellet & 240 & & \\
\hline \multirow{2}{*}{$\begin{array}{l}\text { Phytase SP(1) } \\
(250-400 \mu \mathrm{m})\end{array}$} & \multirow{2}{*}{85} & Unconditioned Mash & 350 & \multirow{2}{*}{42.86} & \multirow{2}{*}{0.23} \\
\hline & & Pellet & 150 & & \\
\hline \multirow{2}{*}{ Phytase LBD (2) } & \multirow{2}{*}{85} & Unconditioned Mash & 460 & \multirow{2}{*}{50.00} & \multirow{2}{*}{0.24} \\
\hline & & Pellet & 230 & & \\
\hline \multirow{2}{*}{ Phytase IBD(2) } & \multirow{2}{*}{85} & Unconditioned Mash & 500 & \multirow{2}{*}{46.00} & \multirow{2}{*}{0.23} \\
\hline & & Pellet & 230 & & \\
\hline \multirow{2}{*}{ Phytase HBD(2) } & \multirow{2}{*}{85} & Unconditioned Mash & 1000 & \multirow{2}{*}{34.00} & \multirow{2}{*}{0.24} \\
\hline & & Pellet & 340 & & \\
\hline
\end{tabular}

${ }^{1}$ Obtained from Eurofins Analytical Lab, Des Moines, lowa

${ }^{2}$ Calculated using the following equation [(Pellet Activity/Mash Activity) $\times 100$ ]

${ }^{3}$ Non Phytate Phosphorus calculated using the following equation [Total Phosphorus - (0.282 x Phytic Acid)] 
Table 5. Broiler Experiment One - Performance Data (Hubbard x Cobb 500 straight run broilers)

\begin{tabular}{|c|c|c|c|c|c|c|c|c|c|c|c|}
\hline Treatment $^{1}$ & $\begin{array}{c}\text { Day } 3 \\
\text { Starting } \\
\text { Pen } \\
\text { Weight }^{2} \\
\text { (kg) }\end{array}$ & $\begin{array}{c}\text { Day } 7 \\
\text { Pen } \\
\text { Weight } \\
\text { (kg) }\end{array}$ & $\begin{array}{c}\text { Day } 14 \\
\text { Pen } \\
\text { Weight } \\
\text { (kg) }\end{array}$ & $\begin{array}{l}\text { Day } 21 \\
\text { Ending } \\
\text { Bird } \\
\text { Weight }^{3} \\
\text { (kg) }\end{array}$ & $\begin{array}{c}\text { Pen } \\
\text { Feed } \\
\text { Intake } \\
\text { (kg) }\end{array}$ & $\begin{array}{c}\text { FCR }^{4} \\
(\mathrm{~kg} / \mathrm{kg})\end{array}$ & $\begin{array}{l}\text { LWG }^{5} \\
(\mathrm{~kg})\end{array}$ & $\begin{array}{c}\text { Percent } \\
\text { Mortality }^{6} \\
\text { (\%) }\end{array}$ & $\begin{array}{c}\text { Tibiae } \\
\text { Ash } \\
\text { Percent }^{7} \\
(\%)\end{array}$ & $\begin{array}{l}\text { Tibia Ash }^{7} \\
\text { (mg/chick) }\end{array}$ & $\begin{array}{c}\text { Tibiae } \\
\text { Ash7,8 } \\
\text { (g/kg of } \\
\text { Body } \\
\text { Weight) }\end{array}$ \\
\hline $\begin{array}{c}\mathrm{NC} \\
(0.25 \mathrm{nPP})\end{array}$ & 0.433 & $0.936^{c}$ & $1.884^{d}$ & $0.454^{\mathrm{e}}$ & $4.223^{e}$ & $1.51^{a}$ & $0.400^{\mathrm{e}}$ & $17.19^{a}$ & $25.082^{e}$ & $399.07^{e}$ & $1.0001^{\mathrm{e}}$ \\
\hline $\begin{array}{c}33 \% \mathrm{PC} \\
(0.32 \mathrm{nPP})\end{array}$ & 0.432 & $0.955^{c}$ & $2.278^{c}$ & $0.563^{d}$ & $5.803^{d}$ & $1.45^{b c}$ & $0.509^{d}$ & $1.56^{b}$ & $26.853^{d}$ & $522.55^{d}$ & $1.0260^{\text {cde }}$ \\
\hline $\begin{array}{c}\mathrm{PC} \\
(0.39 \mathrm{nPP}) \\
\end{array}$ & 0.434 & $1.086^{\mathrm{a}}$ & $2.859^{a}$ & $0.754^{a}$ & $7.638^{a}$ & $1.37^{d}$ & $0.700^{a}$ & $0.00^{b}$ & $33.585^{a}$ & $860.93^{a}$ & $1.2307^{\mathrm{a}}$ \\
\hline $\begin{array}{c}\text { Phytase BR } \\
(177-841 \mu \mathrm{m})\end{array}$ & 0.434 & $1.056^{\mathrm{a}}$ & $2.609^{b}$ & $0.652^{b}$ & $6.780^{b}$ & $1.43^{b c}$ & $0.598^{b}$ & $1.56^{b}$ & $28.915^{b c}$ & $632.63^{b}$ & $1.0579^{b c}$ \\
\hline $\begin{array}{c}\text { Phytase LP } \\
(841-1190 \mu \mathrm{m}) \\
\end{array}$ & 0.433 & $1.034^{\mathrm{ab}}$ & $2.478^{b}$ & $0.609^{c}$ & $6.339^{c}$ & $1.47^{a b c}$ & $0.554^{c}$ & $3.13^{b}$ & $28.350^{c}$ & $585.74^{c}$ & $1.0573^{b c}$ \\
\hline $\begin{array}{c}\text { Phytase SP } \\
(250-400 \mu \mathrm{m})\end{array}$ & 0.434 & $1.040^{\mathrm{a}}$ & $2.595^{b}$ & $0.624^{c}$ & $6.435^{c}$ & $1.41^{\mathrm{cd}}$ & $0.570^{c}$ & $0.00^{b}$ & $27.893^{c}$ & $591.05^{c}$ & $1.0373^{c d}$ \\
\hline $\begin{array}{l}\text { ANOVA P- } \\
\text { Value }\end{array}$ & 0.3640 & $<0.0001$ & $<0.0001$ & $<0.0001$ & $<0.0001$ & 0.0003 & $<0.0001$ & 0.0002 & $<0.0001$ & $<0.0001$ & $<0.0001$ \\
\hline $\mathrm{SEM}^{9}$ & 0.0011 & 0.0185 & 0.0612 & 0.0090 & 0.1039 & 0.0204 & 0.0090 & 2.4906 & 0.3633 & 10.2907 & 0.0125 \\
\hline Fisher's LSD ${ }^{10}$ & --- & 0.0525 & 0.1738 & 0.0254 & 0.2952 & 0.0579 & 0.0254 & 7.0783 & 1.0325 & 29.246 & 0.0356 \\
\hline
\end{tabular}

${ }^{1}$ Treatments $0.25,0.32,0.39$ describe the calculated non phytate phosphorus percentage

2 Starting Pen weights were based on 8 birds per pen

${ }^{3}$ Birds were weighed on the morning of Day 21

${ }^{4}$ FCR=Feed Conversion Ratio, corrected for mortality

${ }^{5}$ LWG=Live Weight Gain/bird

${ }^{6}$ Mortality percentage is based on 8 birds per pen

7 Tibiae were ether extracted to remove residual fat prior to being ashed

${ }^{8}$ Tibia ash $\mathrm{mg} / \mathrm{g}$ of gain= tibia ash (mg/chick)/ LWG (g)

${ }^{9}$ Standard Error of Mean

${ }^{10}$ Fisher's Least Significant Difference

a-e Mean within a column that do not share a common superscript differ $(P \leq 0.05)$ 
Table 6. Broiler Experiment Two- Performance Data (Hubbard x Cobb 500 straight run broilers)

\begin{tabular}{|c|c|c|c|c|c|c|c|c|c|c|c|}
\hline Treatment $^{1}$ & $\begin{array}{c}\text { Day } 3 \\
\text { Starting } \\
\text { Pen } \\
\text { Weight }^{2} \\
\text { (kg) }\end{array}$ & $\begin{array}{c}\text { Day } 7 \\
\text { Pen } \\
\text { Weight } \\
\text { (kg) }\end{array}$ & $\begin{array}{c}\text { Day } 14 \\
\text { Bird } \\
\text { Weight } \\
\text { (kg) }\end{array}$ & $\begin{array}{c}\text { Day } 21 \\
\text { Ending } \\
\text { Bird } \\
\text { Weight }^{3} \\
\text { (kg) }\end{array}$ & $\begin{array}{l}\text { Pen Feed } \\
\text { Intake } \\
\text { (kg) }\end{array}$ & $\begin{array}{c}\text { FCR }^{4} \\
(\mathrm{~kg} / \mathrm{kg})\end{array}$ & $\begin{array}{c}\text { LWG }^{5} \\
\text { (kg) }\end{array}$ & $\begin{array}{c}\text { Percent } \\
\text { Mortality }^{6} \\
\text { (\%) }\end{array}$ & $\begin{array}{c}\text { Tibiae } \\
\text { Ash } \\
\text { Percent }^{7} \\
(\%)\end{array}$ & $\begin{array}{l}\text { Tibia Ash }^{7} \\
\text { (mg/chick) }\end{array}$ & $\begin{array}{c}\text { Tibiae } \\
\text { Ash } 7,8 \\
\text { (g/kg of } \\
\text { Body } \\
\text { Weight) }\end{array}$ \\
\hline $\begin{array}{c}\mathrm{NC} \\
(0.23 \mathrm{nPP})\end{array}$ & 0.436 & $0.873^{b}$ & $0.254^{d}$ & $0.427^{e}$ & $3.774^{d}$ & $1.42^{\mathrm{a}}$ & $0.373^{e}$ & $15.63^{a}$ & $27.435^{f}$ & $380.57^{f}$ & $1.0240^{c}$ \\
\hline $\begin{array}{c}33 \% \mathrm{PC} \\
(0.33 \mathrm{nPP})\end{array}$ & 0.435 & $0.954^{a}$ & $0.345^{b c}$ & $0.764^{b}$ & $7.477^{b}$ & $1.35^{b c}$ & $0.709^{b}$ & $3.13^{b}$ & $32.075^{b}$ & $751.78^{b}$ & $1.0600^{b}$ \\
\hline $\begin{array}{c}\mathrm{PC} \\
(0.41 \mathrm{nPP})\end{array}$ & 0.438 & $0.964^{a}$ & $0.369^{a}$ & $0.851^{a}$ & $8.345^{a}$ & $1.32^{c}$ & $0.796^{a}$ & $1.56^{b}$ & $35.353^{a}$ & $956.39^{a}$ & $1.2012^{a}$ \\
\hline Phytase LBD & 0.436 & $0.961^{a}$ & $0.350^{b}$ & $0.748^{b c}$ & $7.214^{b c}$ & $1.35^{b c}$ & $0.693^{b c}$ & $4.69^{b}$ & $31.450^{b c}$ & $710.46^{c}$ & $1.0249^{c}$ \\
\hline $\begin{array}{c}\text { Phytase } \\
\text { IBD }\end{array}$ & 0.437 & $0.958^{a}$ & $0.339^{b c}$ & $0.726^{c d}$ & $7.059^{b c}$ & $1.33^{b c}$ & $0.671^{c d}$ & $1.56^{b}$ & $30.567^{\text {de }}$ & $671.49^{\text {de }}$ & $1.0008^{c d}$ \\
\hline Phytase HBD & 0.436 & $0.944^{a}$ & $0.333^{c}$ & $0.716^{d}$ & $6.957^{c}$ & $1.33^{b c}$ & $0.661^{d}$ & $1.56^{\mathrm{b}}$ & $31.121^{\mathrm{cd}}$ & $669.89^{\text {de }}$ & $1.0138^{\mathrm{cd}}$ \\
\hline $\begin{array}{l}\text { ANOVA P- } \\
\text { Value }\end{array}$ & 0.1489 & 0.0009 & $<0.0001$ & $<0.0001$ & $<0.0001$ & $<0.0001$ & $<0.0001$ & 0.0028 & $<0.0001$ & $<0.0001$ & $<0.0001$ \\
\hline $\mathrm{SEM}^{9}$ & 0.0012 & 0.0143 & 0.0056 & 0.0113 & 0.1499 & 0.0114 & 0.0113 & 2.4906 & 0.2942 & 12.8559 & 0.0122 \\
\hline $\begin{array}{c}\text { Fisher's } \\
\text { LSD }^{10}\end{array}$ & --- & 0.0406 & 0.0158 & 0.0321 & 0.4259 & 0.0324 & 0.0320 & 7.0783 & 0.8362 & 36.5360 & 0.0346 \\
\hline
\end{tabular}

${ }^{2}$ Starting Pen weights were based on 8 birds per pen

${ }^{3}$ Birds were weighed on the morning of Day 21

${ }^{4}$ FCR= Feed Conversion Ratio, corrected for mortality

${ }^{5}$ LWG=Live Weight Gain/bird

${ }^{6}$ Mortality percentage is based on 8 birds per pen

7 Tibiae were ether extracted to remove residual fat prior to being ashed

${ }^{8}$ Tibia ash $\mathrm{mg} / \mathrm{g}$ of gain= tibia ash (mg/chick)/ LWG (g)

${ }^{9}$ Standard Error of Mean

${ }^{10}$ Fisher's Least Significant Difference

a-e Mean within a column that do not share a common superscript differ $(P \leq 0.05)$ 
Chapter 3: The effect of feeder space access and crumble/pellet composition on 38 day broiler performance

M.E. Lemons ${ }^{1}$ and J.S. Moritz III

Division of Animal and Nutritional Sciences, West Virginia University, Morgantown, West Virginia, 26506-6108

Phone: 304-293-1911

Fax: 304-293-2232 
SUMMARY: Research conducted at universities often exposes broilers to conditions that are less stressful than encountered in typical commercial production. Research utilizing small floor pens and industry style feed pans frequently provide much greater feeder space access than broilers receive in commercial barns. Feeder space access could be an important variable influencing research results, especially when coupled with crumble/pellet composition variations. The objective of the current study was to assess the effects of feeder space and crumble/pellet composition on broiler performance. The study utilized a $2 \times 2$ factorial arrangement in a randomized complete block design using the main effects: high or low crumble/pellet composition (70\% vs. $40 \%)$ and increased or industry feeder space access $(5.9 \mathrm{~cm} / \mathrm{bird}$ vs. $1.2 \mathrm{~cm} / \mathrm{bird})$. Diets met Agristat nutrient values and were pelleted at the West Virginia University pilot feed mill. A total of 1,840 Hubbard x Cobb straight run broilers obtained from a commercial hatchery were randomly placed in one of 40 pens with ten replications per treatment. Broilers were individually weighed and feed consumed was recorded at the end of each growth phase to calculate feed intake per bird (FI), live weight gain per bird (LWG), ending bird weight (EBW), and mortality corrected FCR, percent mortality, and pen coefficient of variation for ending bird weight (d38). Feed intake from d1-38 was influenced by a main effect interaction $(\mathrm{P}<0.05)$, demonstrating that birds increased intake when presented a high crumble/pellet composition, especially when provided increased feeder space access. Broilers fed a high crumble/pellet composition from d1-38 demonstrated increased LWG and decreased FCR $(\mathrm{P}<0.05)$. Broilers provided industry feeder space access from d1-38 demonstrated lower LWG and FCR $(\mathrm{P}<0.05)$. Multiple comparison data demonstrated a two point FCR and $130 \mathrm{~g}$ LWG advantage $(\mathrm{P}<0.05)$ for providing a high composition of crumble/pellet using industry feeder space access and a three point FCR and $75 \mathrm{~g}$ LWG advantage $(\mathrm{P}<0.05)$ using increased feeder space access. These data suggest that feeder 
space access affects broiler performance and advantages of providing a high composition of crumble/pellet may best be extrapolated from research utilizing industry feeder space access.

\section{DESCRIPTION OF THE PROBLEM}

Applied research conducted at universities is essential for further advancements in poultry science and ultimately the commercial poultry industry. However, university research farms often expose broilers to conditions less stressful than encountered in typical commercial production. University research often utilizes small floor pens and industry style feed pans that provide greater feeder space access than would be seen in a commercial barn. Feeder space access represents an important variable that may influence research results, especially when coupled with differing composition of crumble/pellet that broilers receive in the feed pan.

Improvements in feed form, such as pelleting, have been shown to improve broiler performance when compared to a mash diet. This is due to improvements in feed intake and productive energy while decreasing ingredient segregation, feed wastage, and pathogens [1-9]. The improvements become greater with high compositions of pellets compared to lower compositions of pellets. Lilly and coauthors determined that improvements in pellet:fine ratio sequentially increased feed intake and LWG with decreased FCR being more of a minor response [3]. The author's linear model indicated that a 10-percentage point increase of intact pellets resulted in a $10 \mathrm{~g}$ increase in carcass weight, a $4 \mathrm{~g}$ increase in breast weight, and a 0.4 point improvement in FCR. This study accounted for variations in bird sex of Cobb x Cobb 500 broilers and utilized a feeder space access of $5.9 \mathrm{~cm} / \mathrm{bird}$.

Effects of feeder space access on commercial broiler performance are not widely reported in past literature. Previous research has shown that feed restriction in the starter phase resulted in improvements in FCR [10,11]. Leone and Estevez demonstrated an increased competition at the 
feed pan when feeder space access was restricted using six week old broilers for one hour observational periods [12]. However, research on feed restriction throughout the entire growth process using current genotypes has not been reported in recent literature. The objectives of the current study were to assess how feeder space access coupled with a high or low composition of crumble/pellet would affect straight run Hubbard x Cobb broiler performance through 1-38d. The crumble/pellet composition was within the range tested in Lilly et al., 2011 [3], and represents feed quality that commercial broilers may encounter in the feed pan.

\section{MATERIALS AND METHODS}

\section{Feed Manufacture}

Dietary treatments were split into three phases: starter (D1-10), grower (D11-22), and finisher (D23-38). All diets were formulated to meet or exceed Agristat nutrient values (Table 1). Feed manufacture was conducted at the West Virginia University Pilot feed mill. Dietary treatments for each phase were batched and mixed using a 1-ton vertical screw Easy Automation Inc. mixer [13]. Diets were then steam conditioned using a $1.3 \times 0.31 \mathrm{~m}$ short-term (10s) California Pellet Mill conditioner at $82{ }^{\circ} \mathrm{C}$ and extruded through a $5 \times 38 \mathrm{~mm}$ pellet die driven by a 40 horsepower California Pellet Mill [14]. These conditions coupled with a pellet throughput within California Pellet Mill model recommendations created the high composition of crumbles in the starter and grower phase and $70 \%$ pellets presented in the finisher phase. Low composition treatments for each phase were created by grinding $33 \%$ of the pelleted batch via hammer mill and mixing with the remaining crumble/pellet to create a lower composition of crumbles in the starter and grower phase and $40 \%$ pellets presented in the finisher phase. Further crumble/pellet attrition occurred due to additional mixing. Production rate was determined by measuring pellet volume 
post extrusion for 60 second sampling periods. Pellet Durability Index (PDI) and Modified Pellet Durability Index (MPDI) were performed using a Pfost tumbler box [15] and the New Holmen Pellet Tester (NHPT) [16] was used to determine pellet durability 24 hours post-pelleting (Table

2). Pellet, crumble, and fine percentages were determine by sieving $22.68 \mathrm{~kg}$ of feed through a column made of one American Society of Agricultural Engineers (ASAE) \#5 sieve and one ASAE \#14 sieve and weighing retained feed. Pellets were defined as feed retained on the ASAE \# 5 sieve and crumbles were defined as feed retained on the ASAE \#14 sieve. Feed passing through the ASAE \# 14 sieve were considered fines. Particle size and particle size standard deviation was determined using a $100 \mathrm{~g}$ representative sample passed through a RO-TAP RX-29 for a 10 minute processing period [17]. Descriptive data for the composition of feed presented to broilers during each phase is presented in Table 2.

\section{Live Bird Performance}

Treatment structure was a $2 \times 2$ factorial arrangement in a randomized complete block design using the main effects: high or low crumble/pellet composition (70\% vs 40\%) and increased or industry feeder space access $(5.9 \mathrm{~cm} /$ bird vs $1.2 \mathrm{~cm} / \mathrm{bird})$. A total of 1,840 Hubbard x Cobb straight run broiler chicks obtained from a commercial hatchery [18] were raised in $1.22 \mathrm{~m} \times 2.44$ m floor pens using built-up litter treated with poultry litter treatment $\left(\mathrm{PLT}^{\circledR}\right)$ [19]. Each treatment was replicated 10 times to create a total of 40 pens with 46 broilers/pen. The industry feeder space access treatment was based on local commercial production and feed pan manufacturer's recommendations for small broilers $(1.1 \mathrm{~cm} /$ bird to $1.7 \mathrm{~cm} / \mathrm{bird})$ [20]. Each pen contained two feed hoppers with $136 \mathrm{~cm}$ each of feed access (circumference). Restrictor plates were created from $0.5 \mathrm{~cm}$ thick wood laminate to mimic small, commercial broiler practices and recommendations. These were able to be placed over feed pans resulting in a restricted feed access of $27 \mathrm{~cm}$ for each 
hopper. Treatments containing the laminate restrictor plate were referred to as "industry" and had a feeder space access of $1.2 \mathrm{~cm} / \mathrm{bird}$. Treatments that did not contain the wood laminate restrictor plate were referred to as "increased" and had a feeder space access of $5.9 \mathrm{~cm} / \mathrm{bird}$. Industry or increased treatments were combined with a high or low composition of crumble/pellet. Mortalities from D1-3 were replaced. Birds were individually weighed and feed intake was calculated at the end of each growth phase (D10, 22, and 38). Variables measured included feed intake/bird (FI), live weight gain/bird (LWG), ending bird weight (EBW), mortality corrected FCR, percent mortality, and pen coefficient of variation for ending bird weight (d38). Breast weight and breast yield of ending bird weight was performed at the end of the finisher phase using 4 male birds \pm 100 grams of the pen mean. All birds were reared using environmental recommendations obtained from Cobb-Vantress [21]. All methodologies were compliant with protocol (14-0704) approved by the West Virginia University Animal Care and Use Committee.

\section{Statistical Analysis}

Variables were analyzed in a $2 \times 2$ factorial arrangement in a randomized complete block design using one-way ANOVA considering the main effects: high or low crumble/pellet composition (70\% vs 40\%) and increased or industry feeder space access $(5.9 \mathrm{~cm} / \mathrm{bird}$ vs 1.2 $\mathrm{cm} / \mathrm{bird}$ ) and interactions. Treatments were further analyzed using Fisher's LSD multiple comparison test. The experimental unit was one pen containing 46 straight run broilers. Blocking criterion consisted of pen location in the research barn. Data collected for the starter (D1-10), grower (D11-22), finisher (D23-38), and overall (D1-38) were analyzed using the GLM procedure of SAS [22]. Alpha was designated as 0.05 and letter superscripts were used to denote differences among treatment means. 


\section{RESULTS AND DISCUSSION}

Data for each phase of the study, as well as the overall period (d1-38) are presented in Tables 3-6. Overall FI was influenced by a main effect interaction ( $\mathrm{P}=0.047$, Table 6) demonstrating that broilers increased intake when presented a high crumble/pellet composition, especially when provided increased feeder space access. During the starter phase, FI was only increased due to increased feeder space access $(\mathrm{P}<0.05$, Table 3$)$. However, the grower and finisher phase demonstrated a similar interaction and trend towards an interaction respectively (Tables 4 and 5), as demonstrated for the overall study, where broilers increased intake when presented a high crumble/pellet composition, especially when provided increased feeder space access.

Overall growth period data demonstrated an improved FCR for main effects associated with high crumble/pellet composition and industry feeder space access $(\mathrm{P}<0.05$, Table 6$)$. The starter phase demonstrated similar effects $(\mathrm{P}<0.05$, Table 3$)$. Grower FCR was influenced by a main effect interaction $(\mathrm{P}=0.0019$, Table 4$)$ demonstrating that birds receiving industry feeder space access resulted in improved efficiency regardless of feed composition. The main effect of feed composition demonstrated improved FCR during the finisher phase in favor of high crumble/pellet composition with no feeder space access effect (Table 5). Improvements associated with restriction of feeder space in the starter phase resulting in improved FCR seen by Deaton and Fontana were similar to results seen for the overall study $[10,11]$.

Overall growth period and grower period LWG demonstrated that main effects associated with high crumble/pellet composition and increased feeder space access resulted in the largest gain (Tables 4 and 6, $\mathrm{P}<0.05)$. Similar trends were associated with the starter phase $(\mathrm{P}=0.07$, Table 3$)$. Finisher period LWG was only increased due to feeding high pellet composition $(\mathrm{P}=0.0002$, Table 
5). The main effects associated with feed composition and feeder space access demonstrated significance for breast weight $(\mathrm{P}<0.05$, Table 6$)$, with high crumble/pellet composition and increased feeder space resulting in a 24 gram and 18 gram improvement respectively. The high crumble/pellet composition resulted in an eight gram increase in breast weight and 0.7 point improvement in FCR per a 10 percentage point increase of intact pellets, similar to the $4 \mathrm{~g}$ increase in breast weight and 0.4 point FCR improvement observed by Lilly et al., 2011 [3]. Performance gain differences in response to pellet composition between the current study and Lilly et al., 2011 [3] may be associated with variations in genetic strain.

The CV of EBW was not effected by treatment (P>0.05, Table 5). However, the low crumble/pellet composition resulted in a numerically lower $\mathrm{CV}$ regardless of feeder space access. Competition at the feeder for consumption of crumble/pellet likely resulted in dominant birds increasing their intake and growth while less dominant birds consumed more fines and grew less. Leone and Eztevez demonstrated increased competition at the feed pan when feeder space access was more restricted [12]. Past literature has suggested that intense directional selection for a trait may lead to phenotypic variation because the extreme individuals with a higher selection probability are also the genotypes passing down high variability [23-25].

Overall multiple comparison of treatment means demonstrated a two point FCR and $130 \mathrm{~g}$ LWG advantage $(\mathrm{P}<0.05)$ for providing a high crumble/pellet composition using industry feeder space access compared to a three point FCR and $75 \mathrm{~g}$ LWG advantage $(\mathrm{P}<0.05)$ using increased feeder space access. These data suggest that feeder space access affects broiler performance and advantages of providing a high crumble/pellet composition may best be extrapolated from research utilizing a feeder space access similar to commercial conditions. 


\section{CONCLUSIONS AND APPLICATIONS}

1.) Feeding a high composition of crumble/pellet (70\%) resulted in improved Hubbard x Cobb 1$38 \mathrm{~d}$ performance compared to feeding a low composition of crumble/pellet (40\%)

2.) Feeder space access influenced Hubbard $x$ Cobb 1-38d performance and interacted with the feed composition main effect, therefore future research should consider feeder space access so that results are most relevant to the commercial broiler industry 


\section{REFERENCES AND NOTES}

1.) Behnke, K.C. 1996. Feed manufacturing technology: Current issues and challenges. Animal Feed Science and Technology. 62:49-57

2.) Buchanan N.P, Moritz J.S. 2009. Main effects and interactions of varying formulation protein, fiber, and moisture on feed manufacture and pellet quality. Journal of Applied Poultry Research. 18(2):274-283

3.) Lilly, K.G.S. et al. 2011. Examining the relationships between pellet quality, broiler performance, and bird sex. Journal of Applied Poultry Research. 20(2):231-239

4.) Reece, F.N. et al. 1986. The effects of hammer mill screen size on ground corn particle size, pellet durability, and broiler performance. Journal of Poultry Science. 65(7):1257-1261

5.) Wondra, K.J. et al. 1995. Effect of particle size and pelleting on growth performance, nutrient digestibility, and stomach morphology in finishing pigs. Journal of Animal Science. 73:757-763

6.) Cutlip, S.E. et al. 2008. Effect of steam conditioning practices on pellet quality and growing broiler nutritional value. Journal of Applied Poultry Research. 17(2):249-261

7.) Hott, J.M. et al. 2008. The effect of moisture addition with a mold inhibitor on pellet quality, feed manufacture, and broiler performance. Journal of Applied Poultry Research. 17:262-271

8.) Fairchild, F. and Greer, D. 1999. Pelleting with precise mixer moisture control. Feed International Magizine. Aug:32-36

9.) Gehring, C.K. et al. 2011. Increasing mixer-added fat reduces the electrical energy required for pelleting and improves exogenous enzyme efficacy for broilers. Journal of Applied Poultry Research. 20:75-89

10.) Deaton, J.W. 1995. The effect of early feed restriction on broiler performance. Journal of Poultry Science. 74:1280-1286

11.) Fontana, E.A. et al. 1992. Effect of early feed restriction on growth, feed conversion, and mortality in broiler chickens. Journal of Poultry Science. 72:1296-1305.

12.) Leone, E.H., Eztévez, I. 2008. Space use according to the distribution of resources and level of competition. Journal of Poultry Science. 87:3-13

13.) MFP Vertical Mixer, Easy Automation Inc., Welcome, MN.

14.) Master Model Pellet Mill, California Pellet Mills Company, Crawfordsville, IN.

15.) American Society for Agricultural Engineers. 1983. Methods for determining and expressing fineness of feed materials by sieving. Page 325 in American Society of Agricultural Engineers Standard S 319. Am. Soc. Agric. Eng. Yearbook Standards, Am. Soc. Am. Eng., St. Joseph, MI. Pellet durability index was determined by sifting $500 \mathrm{~g}$ of pellets from a treatment through a No. 5 American Society for Testing and Materials (ASTM) screen before being deposited into a Pfost tumbler. The sifted pellets were then tumbled in the container, dimensions $5 \times 12 \times 12$ in., with a $2 \times 9$ in. plate fixed diagonally along the $12 \times 12 \mathrm{in}$. side, for approximately $10 \mathrm{~min}$ at $50 \mathrm{rpm}$. The sample was then sifted again through the No. 5 (ASTM) mm screen, weighed, and the percentage 
of pellets was calculated by dividing the weight of pellets after tumbling by the weight of pellets before tumbling and then multiplying that value by 100 . Modified pellet durability index was similarly measured, with the exception of the addition of five, $13-\mathrm{mm}$ hexagonal bolts to the 500 $\mathrm{g}$ of sample in the tumbler. Both analyses are meant to simulate the deleterious effects of transferring and handling the pellets

16.) Pellet quality was assessed one day following production using the New Holmen Portable Pellet Durability Tester, Lignotech USA, INC., Rothschild, WI. $100 \mathrm{~g}$ of pellets were sifted through No. 5 American Society for Testing and Materials (ASTM) screen and placed in holding chamber, blown for 30 seconds by a jet of air, then weighed, giving a direct read of pellet durability. Fines are removed during the blowing process.

17.) RO-Tap RX-29, W.S. Tyler, Mentor, OH

18.) Pilgrim's Pride Hatchery. Moorefield, WV

19.) Poultry Litter Treatment (Sodium Bisulfate)-Jones-Hamilton Ag. Co

20.) Chore-Time Poultry Production Systems. Milford,IN

21.) Cobb-Vantress, Siloam Springs, AR. 2008. Cobb 500 Broiler Performance and Nutrition Supplement.

22.) SAS Institute. 2000. The SAS System for Windows 2000. Release 8.1. SAS Inst. Inc., Cary, NC.

23.) Mulder HA, Bijma P, Hill WG. 2007. Prediction of breeding values and selection responses with genetic heterogeneity of environmental variance. Genetics. 175:1895-1910.

24.) Hill WG. 1984. On selection among groups with heterogeneous variance. Anim Prod.39:473477.

25.) Hill WG, Zhang X-S. 2004. Effects on phenotypic variability of directional selection arising through genetic differences in residual variability. Genet Res. 83:121-131. 
Table 1: Diet Composition of starter, grower, and finisher diets fed to Hubbard X Cobb Broilers

\begin{tabular}{|c|c|c|c|}
\hline & Starter & Grower & Finisher \\
\hline Ingredient & Inclusion, \% & Inclusion, \% & Inclusion, \% \\
\hline Corn & 56.85 & 61.61 & 68.16 \\
\hline Soybean Meal (48\%) & 31.18 & 26.31 & 20.23 \\
\hline Meat and Bone Meal & 5.00 & 5.00 & 5.00 \\
\hline Animal and Vegetable Blend Fat & 3.49 & 3.61 & 3.42 \\
\hline Dicalcium Phosphate & 1.54 & 1.31 & 1.29 \\
\hline Limestone & 0.74 & 0.66 & 0.65 \\
\hline DL-Methionine & 0.32 & 0.31 & 0.22 \\
\hline Sodium Chloride & 0.30 & 0.35 & 0.32 \\
\hline Vitamin/Trace Mineral Premix ${ }^{1}$ & 0.25 & 0.25 & 0.25 \\
\hline L-Lysine $\mathrm{HCl}$ & 0.21 & 0.18 & 0.17 \\
\hline L-Threonine & 0.09 & 0.28 & 0.26 \\
\hline Chlorotetracycline $^{2}$ & 0.03 & 0.00 & 0.03 \\
\hline BMD $60^{3}$ & 0.00 & 0.08 & 0.00 \\
\hline Coban $90^{4}$ & 0.00 & 0.05 & 0.00 \\
\hline \multicolumn{4}{|c|}{ Calculated Nutrients } \\
\hline Metabolizable Energy (kcal/kg) & 3,055 & 3,105 & 3,161 \\
\hline Crude Protein $(\%)$ & 22.40 & 20.60 & 18.09 \\
\hline Digestible Lysine (\%) & 1.19 & 1.05 & 0.90 \\
\hline Digestible TSAA (\%) & 0.88 & 0.83 & 0.69 \\
\hline Digestible Threonine (\%) & 0.77 & 0.89 & 0.79 \\
\hline Calcium (\%) & 1.15 & 1.06 & 1.04 \\
\hline Available Phosphorus (\%) & 0.60 & 0.55 & 0.54 \\
\hline Sodium $(\%)$ & 0.17 & 0.19 & 0.18 \\
\hline
\end{tabular}

${ }^{1}$ Supplied per kg of diet: manganese, $0.02 \%$; zinc $0.02 \%$; iron, $0.01 \%$; copper, $0.0025 \%$; iodine, $0.0003 \%$; selenium, $0.00003 \%$; folic acid, 0.69mg; choline, 386mg' riboflavin, 6.61 mg; biotin, 0.03mg; vitamin B6, 1.38mg; niacin, 27.56mg; pantothenic acid, $6.61 \mathrm{mg}$; thiamine, 2.20mg; manadione, $0.83 \mathrm{mg}$; vitamin B12, 0.01mg; vitamin E, $16.53 \mathrm{IU}$; vitamin D3, $2133 \mathrm{ICU}$; vitamin A, $7716 \mathrm{IU}$

${ }^{2}$ Chlorotetracycline $110 \mathrm{~g} / \mathrm{kg}$ (55g/1,000 kg inclusion; Zoetis Inc. Florham Park, NJ), for an increased rate of live weight gain and improved FCR

${ }^{3}$ Bacitracin methylene disalicylate, $132 \mathrm{~g} / \mathrm{kg}$ (66 g/1,000 kg inclusion; Alpharma, Fort Lee, NJ), for an increased rate of live weight gain and improved FE

${ }^{4}$ Monensin sodium, $198 \mathrm{~g} / \mathrm{kg}$ (99 g/1,000 kg inclusion; Elanco Animal Health, Indianapolis, IN)- , as an aid in the prevention of coccidiosis caused by Eimeria necatrix, Eimeria tenella, Eimeria acervulina, Eimeria brunette, Eimeria mivati, and, Eimeria maxi 
Table 2: Descriptive Feed Manufacture Data

\begin{tabular}{|c|c|c|c|c|c|c|c|c|c|c|}
\hline Phase & $\begin{array}{c}\text { Conditioning } \\
\text { Temperature } \\
\left({ }^{\circ} \mathbf{C}\right)\end{array}$ & $\begin{array}{l}\text { Production Rate } \\
\text { (tonne/hr) }\end{array}$ & $\begin{array}{c}\text { Average NHPT } \\
(\%)\end{array}$ & $\underset{(\%)}{\text { Average } \text { PDI }^{2}}$ & $\begin{array}{c}\text { Average MPDI } \\
(\%)\end{array}$ & Composition & Pellets $^{4}$ & Crumbles $^{5}$ & Fines $^{6}$ & $\begin{array}{l}\text { Average Particle } \\
\operatorname{Size}^{7}(\mu \mathrm{m}) \pm \mathrm{SD}\end{array}$ \\
\hline \multirow{2}{*}{ Starter } & \multirow{2}{*}{82} & \multirow{2}{*}{0.92} & \multirow{2}{*}{59.43} & \multirow{2}{*}{73.36} & \multirow{2}{*}{65.41} & Low & 0.06 & 44.76 & 55.18 & $951 \pm 1.91$ \\
\hline & & & & & & High & 0.11 & 60.61 & 39.28 & $1191 \pm 1.82$ \\
\hline \multirow{2}{*}{ Grower } & \multirow{2}{*}{82} & \multirow{2}{*}{0.90} & \multirow{2}{*}{52.70} & \multirow{2}{*}{70.61} & \multirow{2}{*}{60.07} & Low & 1.98 & 48.94 & 49.08 & $1096 \pm 2.09$ \\
\hline & & & & & & High & 12.70 & 67.10 & 20.20 & $2133 \pm 1.81$ \\
\hline \multirow{2}{*}{ Finisher } & \multirow{2}{*}{82} & \multirow{2}{*}{0.86} & \multirow{2}{*}{58.14} & \multirow{2}{*}{74.23} & \multirow{2}{*}{65.60} & Low & 39.49 & 27.49 & 33.02 & $2145 \pm 2.38$ \\
\hline & & & & & & High & 69.79 & 19.92 & 10.29 & $4197 \pm 1.51$ \\
\hline
\end{tabular}

${ }^{1}$ New Holman Pellet Tester

2 Pellet Durability Index (Pfost tumbler)

${ }^{3}$ Modified Pellet Durability Index (Pfost tumbler)

4-622.68 kg sifted through ASAE \# 5 and \# 14 sieve column; ${ }^{4}$ Pellets- Retained on \#5 sieve, ${ }^{5}$ Crumbles- Retained on \#14 sieve, ${ }^{6}$ Fines- unretained feed

${ }^{7}$ Pellets were ground using roller mill; Particle Size determined using RO-TAP RX-29 for 10 minutes 
Table 3: Starter (D1-10) Comparisons of dietary treatments on broiler performance

\begin{tabular}{|c|c|c|c|c|c|c|c|}
\hline $\begin{array}{c}\text { Feed } \\
\text { Composition }\end{array}$ & $\begin{array}{l}\text { Feeder } \\
\text { Space } \\
\text { Access }\end{array}$ & $\begin{array}{c}\text { Starting } \\
\text { Pen } \\
\text { Weight } \\
\text { (kg) }\end{array}$ & $\begin{array}{c}\text { Feed } \\
\text { Intake/bird } \\
(\mathbf{k g})\end{array}$ & $\begin{array}{c}\text { LWG/bird }^{1} \\
(\mathrm{~kg})\end{array}$ & $\begin{array}{c}\text { Ending } \\
\text { Bird } \\
\text { Weight } \\
\text { (kg) }\end{array}$ & $\begin{array}{c}\text { FCR }^{2} \\
(\mathrm{~kg} / \mathrm{kg})\end{array}$ & $\begin{array}{c}\text { Percent } \\
\text { Mortality } \\
(\%)\end{array}$ \\
\hline \multirow{2}{*}{ High $^{3}$} & Increased $^{5}$ & 2.109 & $0.252^{\mathrm{ab}}$ & $0.195^{\mathrm{a}}$ & $0.241^{\mathrm{a}}$ & $1.29^{\mathrm{bc}}$ & 0.43 \\
\hline & Industry $^{6}$ & 2.100 & $0.243^{\mathrm{c}}$ & $0.190^{\mathrm{ab}}$ & $0.236^{\mathrm{ab}}$ & $1.28^{\mathrm{c}}$ & 0.22 \\
\hline \multirow{2}{*}{ Low $^{4}$} & Increased & 2.100 & $0.260^{\mathrm{a}}$ & $0.190^{\mathrm{ab}}$ & $0.236^{\mathrm{ab}}$ & $1.36^{\mathrm{a}}$ & 0.22 \\
\hline & Industry & 2.097 & $0.245^{\mathrm{bc}}$ & $0.187^{\mathrm{b}}$ & $0.232^{\mathrm{b}}$ & $1.31^{\mathrm{b}}$ & 0.22 \\
\hline \multicolumn{2}{|c|}{ ANOVA P-value } & 0.6435 & 0.0031 & 0.0411 & 0.0317 & $<0.0001$ & 0.8868 \\
\hline \multicolumn{2}{|c|}{ SEM $^{7}$} & 0.0068 & 0.0031 & 0.0019 & 0.0019 & 0.0110 & 0.2353 \\
\hline \multicolumn{8}{|c|}{ Marginal Means-Feed Form } \\
\hline \multicolumn{2}{|c|}{ High Composition } & 2.105 & 0.248 & 0.193 & 0.238 & $1.284^{\mathrm{b}}$ & 0.33 \\
\hline \multicolumn{2}{|c|}{ Low Composition } & 2.099 & 0.252 & 0.189 & 0.234 & $1.339^{\mathrm{a}}$ & 0.22 \\
\hline \multicolumn{8}{|c|}{ Marginal Means-Feeder Space Access } \\
\hline \multicolumn{2}{|c|}{ Increased } & 2.105 & $0.256^{\mathrm{a}}$ & 0.193 & 0.239 & $1.327^{\mathrm{a}}$ & 0.33 \\
\hline \multicolumn{2}{|c|}{ Industry } & 2.099 & $0.244^{\mathrm{b}}$ & 0.189 & 0.234 & $1.296^{\mathrm{b}}$ & 0.22 \\
\hline \multicolumn{8}{|c|}{ Main Effects and Interactions } \\
\hline \multicolumn{2}{|c|}{ Feed Composition } & 0.4225 & 0.1464 & 0.0739 & 0.0635 & $<0.0001$ & 0.6501 \\
\hline \multicolumn{2}{|c|}{ Feeder Space Access } & 0.4116 & 0.0007 & 0.0641 & 0.0546 & 0.0090 & 0.6501 \\
\hline \multicolumn{2}{|c|}{$\begin{array}{l}\text { Feed Composition } \mathrm{x} \\
\text { Feeder Space Access }\end{array}$} & 0.6829 & 0.4274 & 0.8051 & 0.7810 & 0.1018 & 0.6501 \\
\hline
\end{tabular}

${ }^{1}$ LWG $=$ Live Weight Gain

${ }^{2} \mathrm{FCR}=$ Feed Conversion Ratio, corrected for mortality

${ }^{3}$ High Composition= 1191 micron crumble

${ }^{4}$ Low Composition= 951 micron crumble

${ }^{5}$ Increased Access $=5.9 \mathrm{~cm} / \mathrm{bird}$ of feeder space access

${ }^{6}$ Industry Access $=1.2 \mathrm{~cm} / \mathrm{bird}$ of feeder space access

${ }^{7} \mathrm{SEM}=$ Standard Error of the Mean $(n=10)$ 
Table 4: Grower (D11-22) Comparisons of dietary treatments on broiler performance

\begin{tabular}{|c|c|c|c|c|c|c|}
\hline $\begin{array}{c}\text { Feed } \\
\text { Composition }\end{array}$ & $\begin{array}{c}\text { Feeder Space } \\
\text { Access }\end{array}$ & $\begin{array}{c}\text { Feed } \\
\text { Intake/bird } \\
(\mathbf{k g})\end{array}$ & $\begin{array}{c}\text { LWG/bird }^{1} \\
(\mathrm{~kg})\end{array}$ & $\begin{array}{c}\text { Ending } \\
\text { Bird } \\
\text { Weight } \\
\text { (kg) }\end{array}$ & $\begin{array}{c}\text { FCR }^{2} \\
(\mathbf{k g} / \mathbf{k g})\end{array}$ & $\begin{array}{l}\text { Percent } \\
\text { Mortality } \\
(\%)\end{array}$ \\
\hline \multirow{2}{*}{ High $^{3}$} & Increased $^{5}$ & $1.068^{\mathrm{a}}$ & $0.722^{\mathrm{a}}$ & $0.963^{\mathrm{a}}$ & $1.48^{\mathrm{b}}$ & 0.43 \\
\hline & Industry $^{6}$ & $1.036^{\mathrm{b}}$ & $0.713^{\mathrm{a}}$ & $0.949^{\mathrm{a}}$ & $1.45^{\mathrm{c}}$ & 0.87 \\
\hline \multirow{2}{*}{ Low $^{4}$} & Increased & $1.065^{\mathrm{a}}$ & $0.692^{\mathrm{b}}$ & $0.928^{\mathrm{b}}$ & $1.54^{\mathrm{a}}$ & 0.43 \\
\hline & Industry & $0.997^{\mathrm{c}}$ & $0.680^{\mathrm{b}}$ & $0.913^{\mathrm{b}}$ & $1.47^{\mathrm{bc}}$ & 0.43 \\
\hline \multicolumn{2}{|c|}{ ANOVA P-value } & $<0.0001$ & $<0.0001$ & $<0.0001$ & $<0.0001$ & 0.6367 \\
\hline \multicolumn{2}{|c|}{ SEM $^{7}$} & 0.0061 & 0.0052 & 0.0060 & 0.0071 & 0.2863 \\
\hline \multicolumn{7}{|c|}{ Marginal Means-Feed Form } \\
\hline \multirow{2}{*}{\multicolumn{2}{|c|}{$\begin{array}{l}\text { High Composition } \\
\text { Low Commosition }\end{array}$}} & $1.052^{\mathrm{a}}$ & $0.717^{\mathrm{a}}$ & $0.956^{\mathrm{a}}$ & $1.468^{\mathrm{b}}$ & 0.65 \\
\hline & & $1.031^{\mathrm{b}}$ & $0.686^{\mathrm{b}}$ & $0.920^{\mathrm{b}}$ & $1.503^{\mathrm{a}}$ & 0.43 \\
\hline \multicolumn{2}{|c|}{ Low Composilion } & Iarginal Mea & s-Feeder Spa & ccess & & \\
\hline \multirow{2}{*}{\multicolumn{2}{|c|}{ Industry }} & $1.067^{\mathrm{a}}$ & $0.707^{\mathrm{a}}$ & $0.945^{\mathrm{a}}$ & $1.510^{\mathrm{a}}$ & 0.43 \\
\hline & & $1.016^{\mathrm{b}}$ & $0.697^{\mathrm{b}}$ & $0.931^{\mathrm{b}}$ & $1.461^{\mathrm{b}}$ & 0.65 \\
\hline \multicolumn{7}{|c|}{ Main Effects and Interactions } \\
\hline \multicolumn{2}{|c|}{ Feed Composition } & 0.0012 & $<0.0001$ & $<0.0001$ & $<0.0001$ & 0.4841 \\
\hline \multicolumn{2}{|c|}{ Feeder Space Access } & $<0.0001$ & 0.0493 & 0.0168 & $<0.0001$ & 0.4841 \\
\hline \multicolumn{2}{|c|}{$\begin{array}{l}\text { Feed Composition } \mathrm{x} \\
\text { Feeder Space Access }\end{array}$} & 0.0052 & 0.7798 & 0.8939 & 0.0019 & 0.4841 \\
\hline
\end{tabular}

${ }^{1}$ LWG $=$ Live Weight Gain

${ }^{2}$ FCR $=$ Feed Conversion Ratio, corrected for mortality

${ }^{3}$ High Composition= 2133 micron crumble

${ }^{4}$ Low Composition= 1096 micron crumble

${ }^{5}$ Increased Access $=5.9 \mathrm{~cm} / \mathrm{bird}$ of feeder space access

${ }^{6}$ Industry Access $=1.2 \mathrm{~cm} / \mathrm{bird}$ of feeder space access

${ }^{7} \mathrm{SEM}=$ Standard Error of the Mean $(n=10)$ 
Table 5: Finisher (D23-38) Comparisons of dietary treatments on broiler performance

\begin{tabular}{|c|c|c|c|c|c|c|c|}
\hline $\begin{array}{c}\text { Feed } \\
\text { Composition }\end{array}$ & $\begin{array}{c}\text { Feeder Space } \\
\text { Access }\end{array}$ & $\begin{array}{c}\text { Feed } \\
\text { Intake/bird } \\
(\mathbf{k g})\end{array}$ & $\begin{array}{c}\text { LWG/bird }^{1} \\
(\mathrm{~kg})\end{array}$ & $\begin{array}{c}\text { Ending } \\
\text { Bird } \\
\text { Weight } \\
\text { (kg) }\end{array}$ & $\begin{array}{c}\text { FCR }^{2} \\
(\mathrm{~kg} / \mathrm{kg})\end{array}$ & $\begin{array}{l}\text { Percent } \\
\text { Mortality } \\
(\%)\end{array}$ & $\begin{array}{c}\mathrm{CV}^{3} \text { of } \\
\text { Ending } \\
\text { Bird } \\
\text { Weight } \\
(\%)\end{array}$ \\
\hline \multirow{2}{*}{ High $^{4}$} & Increased $^{6}$ & $2.735^{\mathrm{a}}$ & $1.523^{\mathrm{a}}$ & $2.486^{\mathrm{a}}$ & $1.79^{\mathrm{ab}}$ & 1.74 & 10.596 \\
\hline & Industry $^{7}$ & $2.712^{\mathrm{a}}$ & $1.523^{\mathrm{a}}$ & $2.472^{\mathrm{a}}$ & $1.78^{\mathrm{b}}$ & 1.52 & 10.219 \\
\hline \multirow{2}{*}{ Low $^{5}$} & Increased & $2.683^{\mathrm{a}}$ & $1.483^{\mathrm{a}}$ & $2.411^{\mathrm{b}}$ & $1.81^{\mathrm{a}}$ & 1.09 & 9.806 \\
\hline & Industry & $2.584^{\mathrm{b}}$ & $1.430^{\mathrm{b}}$ & $2.343^{\mathrm{c}}$ & $1.80^{\mathrm{a}}$ & 0.87 & 10.041 \\
\hline \multicolumn{2}{|c|}{ ANOVA P-value } & 0.0016 & 0.0010 & $<0.0001$ & 0.0178 & 0.6659 & 0.4806 \\
\hline \multicolumn{2}{|c|}{ SEM $^{8}$} & 0.0258 & 0.0163 & 0.0199 & 0.0055 & 0.5445 & 0.3621 \\
\hline \multicolumn{8}{|c|}{ Marginal Means-Feed Form } \\
\hline \multirow{2}{*}{\multicolumn{2}{|c|}{$\begin{array}{l}\text { High Composition } \\
\text { Low Composition }\end{array}$}} & $2.723^{\mathrm{a}}$ & $1.523^{\mathrm{a}}$ & $2.479^{\mathrm{a}}$ & $1.787^{\mathrm{b}}$ & 1.63 & 10.408 \\
\hline & & $2.634^{\mathrm{b}}$ & $1.457^{\mathrm{b}}$ & $2.377^{\mathrm{b}}$ & $1.804^{\mathrm{a}}$ & 0.98 & 9.923 \\
\hline & Margina & Means-Feede & ace Acce & & & \\
\hline \multirow{2}{*}{\multicolumn{2}{|c|}{ Increased }} & $2.709^{\mathrm{a}}$ & 1.503 & $2.448^{\mathrm{a}}$ & 1.799 & 1.41 & 10.201 \\
\hline & & $2.648^{\mathrm{b}}$ & 1.477 & $2.407^{\mathrm{b}}$ & 1.792 & 1.19 & 10.129 \\
\hline \multicolumn{8}{|c|}{ Main Effects and Interactions } \\
\hline \multicolumn{2}{|c|}{ Feed Composition } & 0.0005 & 0.0002 & $<0.0001$ & 0.0304 & 0.2390 & 0.1910 \\
\hline \multicolumn{2}{|c|}{ Feeder Space Access } & 0.0122 & 0.1041 & 0.0347 & 0.3311 & 0.6922 & 0.8447 \\
\hline \multicolumn{2}{|c|}{$\begin{array}{l}\text { Feed Composition } \mathrm{x} \\
\text { Feeder Space Access }\end{array}$} & 0.1139 & 0.1081 & 0.1554 & 0.5936 & 1.0000 & 0.4058 \\
\hline
\end{tabular}

\footnotetext{
${ }^{1}$ LWG = Live Weight Gain

${ }^{2} \mathrm{FCR}=$ Feed Conversion Ratio, corrected for mortality

${ }^{3}$ Coefficient of Variation $=($ Standard Deviation/Mean Bird Weight $) * 100$

${ }^{4}$ High Composition $=69.79 \%$ Pellets

${ }^{5}$ Low Composition $=39.49 \%$ Pellets

${ }^{6}$ Increased Access $=5.9 \mathrm{~cm} / \mathrm{bird}$ of feeder space access

${ }^{7}$ Industry Access $=1.2 \mathrm{~cm} / \mathrm{bird}$ of feeder space access

${ }^{8} \mathrm{SEM}=$ Standard Error of the Mean $(n=10)$
} 
Table 6: Overall (D1-38) Comparisons of dietary treatments on broiler performance

\begin{tabular}{|c|c|c|c|c|c|c|c|}
\hline $\begin{array}{c}\text { Feed } \\
\text { Composition }\end{array}$ & $\begin{array}{l}\text { Feeder } \\
\text { Space } \\
\text { Access }\end{array}$ & $\begin{array}{c}\text { Feed } \\
\text { Intake/bird } \\
(\mathbf{k g})\end{array}$ & $\underset{(\mathrm{kg})}{\text { LWG/bird }^{1}}$ & $\begin{array}{c}\text { FCR }^{2} \\
(\mathrm{~kg} / \mathbf{k g})\end{array}$ & $\begin{array}{l}\text { Percent } \\
\text { Mortality } \\
(\%)\end{array}$ & $\begin{array}{c}\text { Breast } \\
\text { Weight }^{3} \\
\text { (g) }\end{array}$ & $\begin{array}{c}\text { Breast } \\
\text { Yield }^{4} \\
(\%)\end{array}$ \\
\hline \multirow{2}{*}{ High $^{5}$} & Increased $^{7}$ & $4.081^{\mathrm{a}}$ & $2.440^{\mathrm{a}}$ & $1.66^{\mathrm{b}}$ & 2.61 & $498.09^{\mathrm{a}}$ & 19.81 \\
\hline & Industry $^{8}$ & $4.014^{\mathrm{a}}$ & $2.426^{\mathrm{a}}$ & $1.64^{\mathrm{c}}$ & 2.61 & $481.24^{\mathrm{ab}}$ & 19.25 \\
\hline \multirow{2}{*}{ Low $^{6}$} & Increased & $4.024^{\mathrm{a}}$ & $2.365^{\mathrm{b}}$ & $1.69^{\mathrm{a}}$ & 1.74 & $475.05^{\mathrm{bc}}$ & 19.45 \\
\hline & Industry & $3.838^{\mathrm{b}}$ & $2.297^{\mathrm{c}}$ & $1.66^{\mathrm{b}}$ & 1.52 & $456.54^{\mathrm{c}}$ & 19.22 \\
\hline \multicolumn{2}{|c|}{ ANOVA P-value } & $<0.0001$ & $<0.0001$ & $<0.0001$ & 0.5519 & 0.0070 & 0.3252 \\
\hline \multicolumn{2}{|c|}{ SEM $^{9}$} & 0.0323 & 0.0199 & 0.0048 & 0.6769 & 7.6886 & 0.2485 \\
\hline \multicolumn{8}{|c|}{ Marginal Means-Feed Form } \\
\hline \multirow{2}{*}{\multicolumn{2}{|c|}{\begin{tabular}{|l|} 
High Composition \\
Low Composition
\end{tabular}}} & $4.047^{\mathrm{a}}$ & $2.433^{\mathrm{a}}$ & $1.651^{\mathrm{b}}$ & 2.61 & $489.67^{\mathrm{a}}$ & 19.53 \\
\hline & & $3.931^{\mathrm{b}}$ & $2.331^{\mathrm{b}}$ & $1.677^{\mathrm{a}}$ & 1.63 & $465.79^{\mathrm{b}}$ & 19.33 \\
\hline \multicolumn{8}{|c|}{ Marginal Means-Feeder Space Access } \\
\hline \multirow{2}{*}{\multicolumn{2}{|c|}{$\frac{\text { Increased }}{\text { Industry }}$}} & $4.053^{\mathrm{a}}$ & $2.403^{\mathrm{a}}$ & $1.675^{\mathrm{a}}$ & 2.17 & $486.57^{\mathrm{a}}$ & 19.63 \\
\hline & & $3.926^{\mathrm{b}}$ & $2.362^{\mathrm{b}}$ & $1.653^{\mathrm{b}}$ & 2.06 & $468.89^{\mathrm{b}}$ & 19.23 \\
\hline \multicolumn{8}{|c|}{ Main Effects and Interactions } \\
\hline \multicolumn{2}{|c|}{ Feed Composition } & 0.0003 & $<0.0001$ & $<0.0001$ & 0.1682 & 0.0021 & 0.4055 \\
\hline \multicolumn{2}{|c|}{ Feeder Space Access } & $<0.0001$ & 0.0348 & 0.0003 & 0.8753 & 0.0194 & 0.1089 \\
\hline \multicolumn{2}{|c|}{$\begin{array}{l}\text { Feed Composition } x \\
\text { Feeder Space Access }\end{array}$} & 0.0470 & 0.1534 & 0.2176 & 0.8776 & 0.9096 & 0.5011 \\
\hline
\end{tabular}

${ }^{1}$ LWG $=$ Live Weight Gain

${ }^{2}$ FCR $=$ Feed Conversion Ratio, corrected for mortality

3,4 4 males \pm 100 grams from each pen's mean were used

${ }^{5}$ High Composition= 1191 micron crumble-Starter, 2133 micron crumble-Grower, $69.79 \%$ Pellets-Finisher

${ }^{6}$ Low Composition= 951 micron crumble- Starter, 1096 micron crumble- Grower, $39.49 \%$ Pellets-Finisher

${ }^{7}$ Increased Access $=5.9 \mathrm{~cm} / \mathrm{bird}$ of feeder space access

${ }^{8}$ Industry Access $=1.2 \mathrm{~cm} / \mathrm{bird}$ of feeder space access

${ }^{9} \mathrm{SEM}=$ Standard Error of the Mean $(n=10)$ 


\section{Curriculum Vitae}

\section{Mark E. Lemons}

• 552A Lewis St. • Morgantown, WV $26505 ・$ mlemons1@ mix.wvu.edu • (304) 661-6286 •

Hard working individual, who also thrives when working in a team setting. Enthusiastic about working and works exceptionally well under pressure.

\section{EDUCATION}

University: West Virginia University

Degree: Bachelor of Science, Animal and Nutritional Sciences

Graduation Date: May 2013

GPA: 3.59

University: West Virginia University

Expected Degree: Master of Science, Nutritional and Food Science

Thesis Title: Assessing feeder space access and commercial phytase production methods on performance of commercial broilers fed pelleted diets.

Expected Graduation Date: May 2015

Current GPA: 3.45

\section{EDUCATION HONORS/AWARDS}

\section{Graduated from Greenbrier East High School in 2009:}

Greenbrier East Academic Champion (2006-2009)

Member of National Honor Society, Greenbrier East HS Chapter (2007-2009)

FFA Greenhand and Chapter Farmer Degrees (2006, 2007)

Greenbrier East HS FFA Chapter Proficiency-Forage (2007)

Greenbrier County 4-H Senior Achievement Award (2007)

\section{Scholarships Received:}

WV Poultry Association Scholarship (2012)

National Poultry FDA Scholarship (2012)

Shuck Memorial Baptist Church Scholarship $(2010,2011)$

Greenbrier Farm Bureau Scholarship (2009)

Lewisburg Rotary Scholarship (2009)

WVU Achievement Award (2009)

West Virginia Promise Scholarship (2009-2013)

West Virginia State Fair Scholarship (2009-2013) 


\section{Awards and Honors:}

Davis College of Agriculture, Forestry, and Consumer Science Dean and President List (1/2010-5/2013) Phi Sigma Theta National Honor Society (3/2011- current)

Member of Golden Key International Honour Society (10/2011-current)

Certificate of Excellence, "Lignosulfonate pellet binder and fat increase broiler feed retention time" Athens, GA; 2012 PSA Annual Meeting

\section{First Author Publications}

\section{Peer-reviewed Manuscripts}

M.E. Lemons and J.S. Moritz. 2015. The effect of feeder space access and crumble/pellet composition on 38 day broiler performance. Journal of Applied Poultry Research. (in preparation)

\section{Abstracts}

M.E. Lemons, K.G.S. Wamsley, A.E. Lamp, A.M. Evans, K.J. Shipe, and J.S. Moritz. 2012. Lignosulfonate pellet binder and fat increase broiler feed retention time. 2012. Poultry Sci. Vol. 91 (Suppl. 1): 130

\section{Co-Author Publications}

\section{Peer-reviewed Manuscripts}

A.E. Lamp, M.E. Lemons, K.G.S. Wamsley, and J.S. Moritz. 2015. The effect of pasture access, breed, and diet on laying hen health, performance, and EPA and DHA content of eggs. Journal of Applied Poultry Research. (in preparation)

\section{Abstracts}

A.E. Lamp, M.E. Lemons, K.G.S. Wamsley, and J.S. Moritz. 2012. The effect of pasture access, breed, and diet on laying

hen health, performance, and EHA and DHA content of eggs. 2012. Poultry Sci. Vol. 91 (Suppl. 1): 133

\section{RESEARCH EXPERIENCE}

\section{National Meeting Paper Presentations}

2012 Poultry Science Association (Athens, GA) (Undergraduate Student)

"Lignosulfonate pellet binder and fat increase broiler feed retention time" 


\section{Graduate Research Assistant Summer 2013-Present}

- Conducted 5 contract studies for Verenium/BASF to determine phytase/xylanase efficacy

- Conducted study “ The effect of feeder space access and crumble/pellet composition on 38 day broiler performance"

- Poster Presentation "The effect of feeder space access and crumble/pellet composition on 38 day broiler performance”, Mid Atlantic Nutrition Conference, Timonium, MD (3/25/2015)

- Attended Mid Atlantic Nutrition Conference (3/24-25/2015)

- Assisted with studies for DSM, VPGC, Alltech, Huvepharma, Nutech, and Aviagen

- Guest Lecturer for AVS 251 Feed Mill Tour (11/10-11/2014, 11/11-12/2013)

- Led Davis College Prospective Students farm tour (11/8/2014)

- Instructed Pendleton County Poultry Judging FFA team for National Competition (11/4/2014)

- Clay County FFA Farm Tour: Presented feed mill application and broiler production (11/3/2014)

- Guest Lecturer in Poultry Production, Preparation for Graduate School (10/24/2014)

- Led group for Charleston 5th grade farm tour (10/17/2014, 10/11/2013)

- Assisted with WVU Family Farm Day (9/27/2014, 10/5/2013)

- Assisted with North Marion Hands-On Ag Day (9/19/2014)

- Led Fieldcrest Hall Freshman Farm tour (9/9/2014)

- Assisted with operation of poultry building at West Virginia State Fair ( 8/7-16/2014, 8/917/2013)

- Attended West Virginia Poultry Association annual summer meeting (7/25/2014)

- Assisted with Moorefield Poultry Week Youth Poultry Judging Contest (7/23/2014)

- Attended West Virginia Poultry Association Turkey Grower dinner (7/22/2014)

- Attended PSA National Meeting; Corpus Christi, Texas (7/14-17/2014)

- Assisted with WV FFA Career Development Events (6/3/2014,6/18/2013)

- Paper Presentation "Effects of granulated phytase particle size distribution on pelleting thermal stability and broiler starter performance” for WVU Blue and Gold Graduate Competition (4/9/2014)

- Assisted with poultry processing demonstration during "Food to Table" workshop in Kingwood, WV $(4 / 5 / 2014)$

- Participated in filming poultry processing video (3/6/2014)

- Attended 2014 International Poultry Expo in Atlanta, Georgia (1/28-30/2014)

- Doddridge County FFA Farm Tour. Presented feed mill application and broiler production $(10 / 23 / 2013)$

- Assisted with Boy Scout Wood/Fire Skills Workshop (10/12/2013)

- Assisted with several processing workshops around the state of West Virginia (Fall 2013-Present)

- Assisted with poultry processing workshop at Doddridge County Fair (8/26/2013)

- Presented lecture, Terminology associated with organic vs. all natural products, WVU Organic Field Day (8/15/2013)

- Judge for Monongalia County 4-H Poultry Competition (8/1/2013)

- Attended PSA National Meeting; San Diego, California (7/22-25/2013) 


\section{Graduate Teaching Assistant}

\section{Spring 2015}

Teaching assistant for Animal Nutrition: ANNU 260 (Role includes grading and supporting instructor as needed)

\section{Spring 2014}

Teaching assistant for Advanced Applied Nutrition II: ANNU 362 (Role includes instruction, preparation of class, grading, and occasional lecturing)

\section{Undergraduate Research Assistant}

\section{Fall 2011-Spring 2013}

- Assisted with studies for Phytex, Poet Nutrition, Verenium, BRI

- Coach for WVU Poultry Team for Spring Contest in LSU (2013)

- Guest Lecturer for WVU Cub Scout Merit Badge University, "Beef Breeds and Common Diseases" (2/9/2013)

- Guest Lecturer for ANNU 362, "Methodologies of Proximate Analysis" (1/28/2013)

- Assisted with North Marion Middle School "Hands-On Ag. Day" (9/20/2012)

- Assisted with operation of the Poultry Building at West Virginia State Fair (8/2012)

- Assisted with WVU Organic Field Day (8/5/2011, 8/4/2012)

- Assisted with Moorefield Poultry Week youth activities (7/24-25/2012)

- Attended 2012 PSA Meeting @ Athens, GA (7/9-12/2012)

- Attended West Virginia Poultry Association Summer Meeting (7/2012)

- Assisted with "Ag in the Classroom"- (6/15/2012)

- Member of WVU Poultry Team @ Spring contest in L.S.U. (2012)

- Attended 2012 International Poultry Expo in Atlanta, Georgia (1/24-26/2012)

- Assisted with WVU Family Farm Day (10/15/2011, 10/13/2012)

- Assisted with "Cub Scouts Day at the Farm" (10/28/2011, 10/15/2012)

- Assisted with WV FFA Career Development events (9/23/2011, 9/26/2012)

- Guest Lecturer for AVS 251 Laboratory $(2011,2012)$

\section{Undergraduate Teaching Assistant}

\section{Spring 2013}

Teaching assistant for Poultry Evaluation: ANPR 339 (Role includes instruction, grading, and preparation of class) 


\section{Summer Undergraduate Research Experience}

\section{Summer 2011}

- Assisted with Organic Pastured Laying Hen Research

- Helped assist with studies for JBS United, Phytex, Poet Nutrition, Vereneium, Virginia Poultry Grower's Coop

- Assisted with organization and running of the Poultry Building at the WV State Fair (8/1618/2011)

- Gave presentation for Poultry Workshop at WVU Organic Field Day (8/4/2011)

- Gave Poster presentation for WVU SURE Research Symposium, Production of omega-3 fatty acid enhance eggs in a pastured poultry system (7/28/2011)

\section{EXPERIENCE}

\section{Lewisburg Veterinary Hospital}

Ran laboratory tests

Assisted with surgeries

Handled animals and cleaned cages

Operated computer system and conducted financial transactions

Completed everyday tasks as needed

\section{Greenbrier County Youth 4-H Camp}

Assisted with everyday tasks as needed

Helped with the teaching of classes

\section{SKILLS}

- Savvy in Microsoft Window's Programs

- Internet Literate

- Poultry Handling, Judging, and Management

- Feed Manufacture and Diet Formulation

- Precision-feeding

- Cecectomy Surgery

- Tibia and Ileum Extraction

- Public Speaking

- Classroom Instruction 
Have completed several agricultural/animal specific courses

\section{Undergraduate}

- Food Microbiology: AEM 445

- Applied Nutrition I and II: ANNU 361,362

- Principles of Genetics: GEN 371

- Environmental Microbiology: AEM 341

- Poultry Evaluation: ANPR 338,339

- Poultry Production/Laboratory: ANPR 367,369

- Beef Production/Laboratory: ANPR 341,343

- Dairy Heifer Management: A\&VS 411

- Animal Nutrition: ANNU 260

- Principles of Animal Science: A\&VS 251

- Companion Animal Science: A\&VS 275

- Intro to Animal Science: A\&VS 150

\section{Graduate}

- Introduction to Biochemistry: AGBI 410

- Nutritional Biochemistry: AGBI 512

- Animal Biotechnology: AGBI 514

- Nutrition/Disease Prevention: HN\&F 614

- Statistical Methods I: STAT 511

- Statistical Methods II: STAT 512

- Grants/Grantsmanship: GRAD 593

References available upon request 